\title{
مسؤولية الناقل البحري عن تلف البضاعة وهلاكها (دراسة هقارنة)
}

م. م أفلاص لطبف مهمد

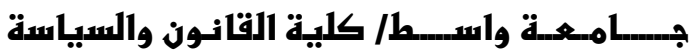

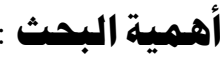

تحتل مسؤولية الناقل البحري مكان الصدارة في الأمور التي ينطوي عليها عقد النقل البحري ، فأحكام مسؤولية الناقل البحري على قدر كبير من الأهمية ، فحيث يخل الناقل بالألتزامـات التي يفرضها القانون أو العقد تتحقق مسؤوليته.

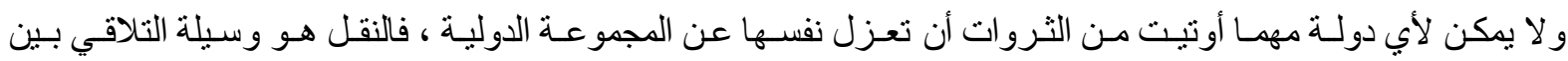

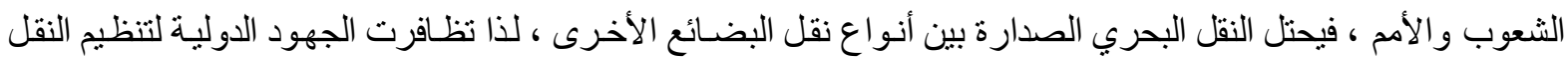

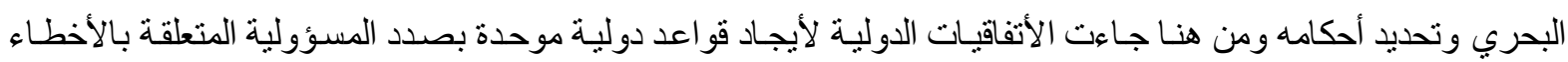

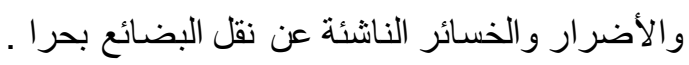

أشكالية البحث

يترنب على تلف البضاعة أو هلاكها ضرر للمرسل اليه نتيجة هذا التلف أو الهلاك ، ومن ثم تبرز مشكلة تعد

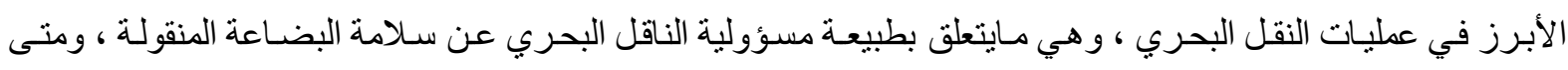

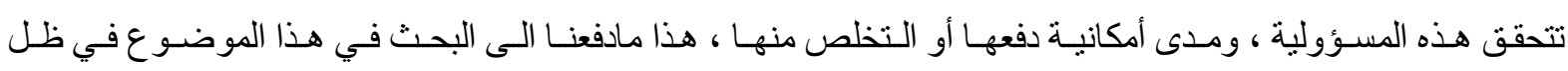
التشريعات والاتفاقيات الدولية.

\section{هنهمية البحث:}

أنبعنا في هذا البحث المنهج المقارن ، حيث تظافرت جهود دوليـة في حل مـا يو اجها النقل البحري للبضـائع من

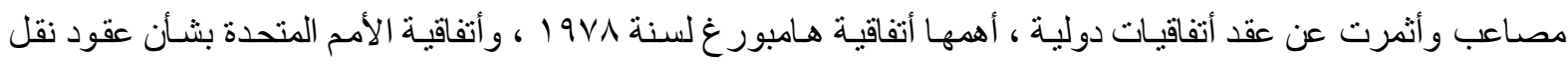

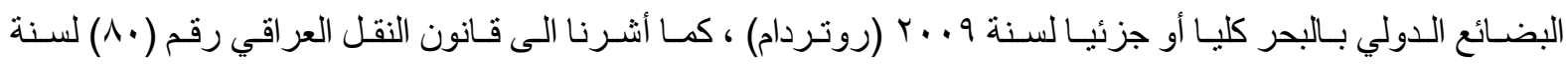

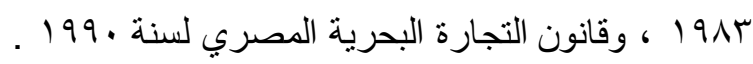

خطة البحث : خ

تناولنـا في المبحث الأول مفهوم التلف أو الهـلاك الذي يصيب البضـاعة جراء عملية النقل البحري ، في حين خصصنا المبحث الثاني لمعرفة اساس وطبيعة مسؤولية الناقل ، واخبرا تناولنا حالات أعفاء الناقل البحري من المسؤولية في المبحث الثالث .

\section{المبحث الأول - هفهوم تلف البضاعة او هلاك البضاعة}

كل تلف او هلاك يصبب البضـاعة يؤثر في قيمتها او في استعمالها لمـا اعلت لـه ، سواء كانت تلف او هلاك

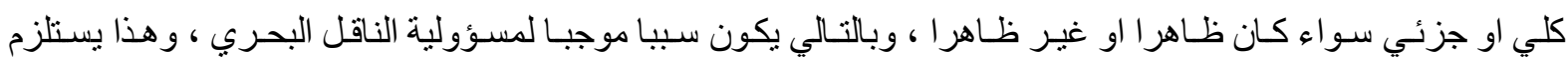

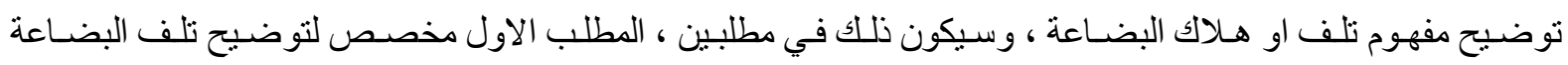
و المطلب الثاني لهلاك البضاعة . 
المطلب الاول- تلف البضاعة

يقصد بتلف البضـاعة وصـولها كاملة من حيث مقدار ها ولكن تالفة ، كفاكهة عطبت او زهور ذبلت او اجهزة

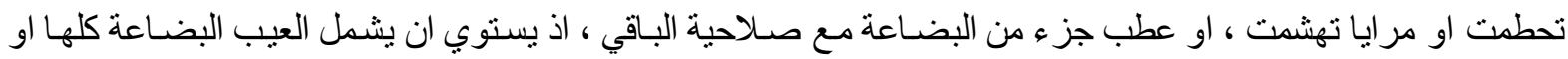

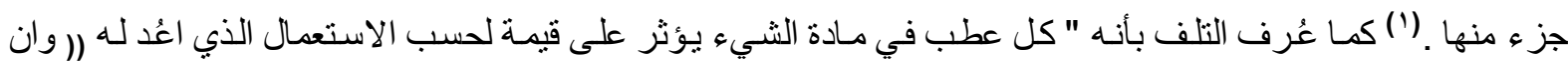
العطب في مـادة الثـيء او سوء حالتهه يعني كونـه لم يعد صـالحا للاستخدام الذي لعُد لله ، او ان استخدامه لم يكن بالثكل

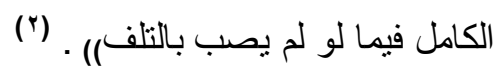
ويذهب البعض الى القول بأنه في حالة تلف جز ء من البضـاعة بحيث لا يصلح الباقي لاستعماله فيمـا اعد لـه هو

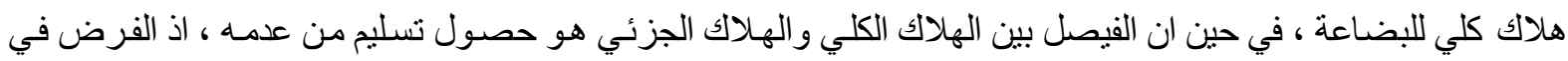

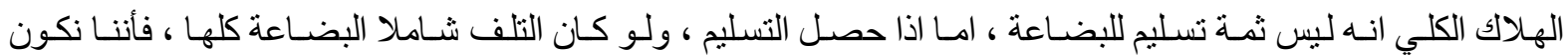

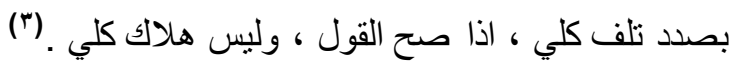
ونلاحظ ممـا تقدم ان معيسار التفرقة بين التلف والهلاك الكلي هو وصـول البضـاعة فقي حالـة الهـلاك الكلي لا

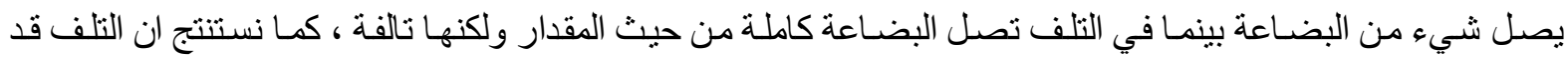

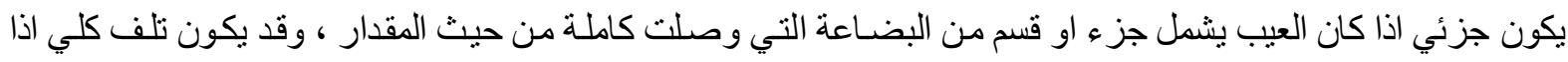
كان العيب يشمل كل البضـاعة التي وصلت كاملة من حيث المقدار ، لكنتـا نرى ان كلا مـن التلف الكلي والهـلاك الكلي يؤديان الى نفس النتيجة من حيث عدم صلاحية البضاعة للاستخدام او لمـا اعدت اليهه فوصول البضـاعة كاملة ولكنها تالفة فئة تماما يستوي مع عدم وصولها نهائيا في حالت الهلاك الكلي حيث تصبح البضاعة غير صالحة للاستخدام .

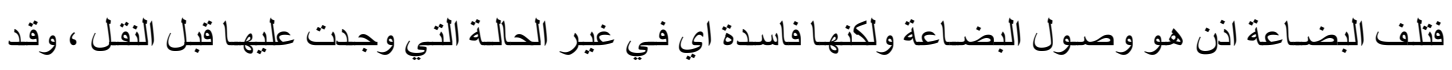
عبرت محكمة النقض المصرية عن ذلك بقولها ان (( مسؤولية امين النقل هي مسؤولية عقديـة تتحقق بإثبات عدم تسليم

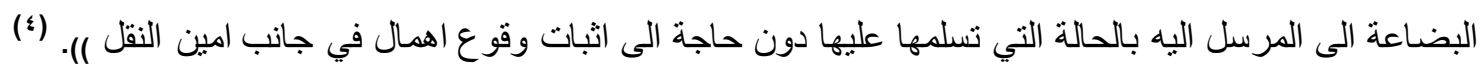
ولم يتطرق قـانون النقل العر اقي رقم (•^) لسنة بر91 الى تعريف التلف ولكنه تطرقه فقط لمسؤولية الناقل

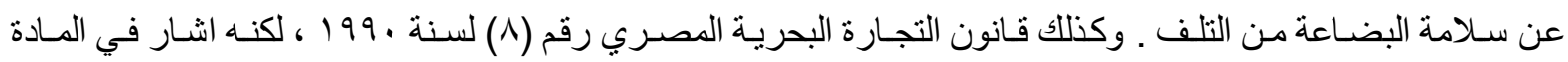

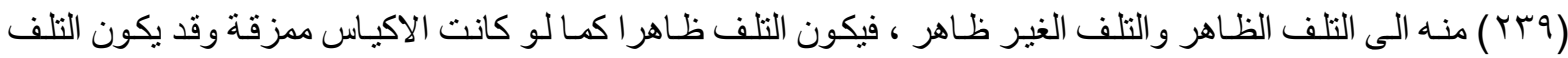
غير ظاهر . (0) و اثبات التلف يقتضي المقارنة بين مدون في سند الثـن بخصوص البيانـات المتعلقة بوصف البضـاعة وحالتها

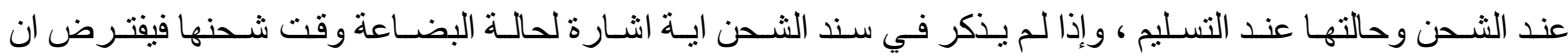

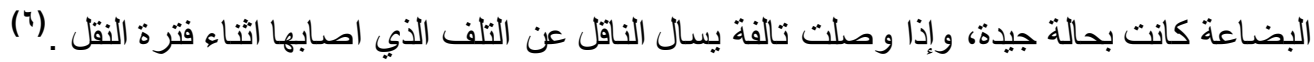
اذ ان لسند الثحن اهمية كبيرة في عملية اثبات التلف الذي يقع عبئه على المرسل اليه، باعتبار ه دائنسا بالبضـائع،

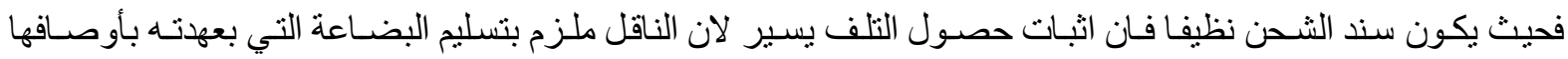
المثبتة في السند ، فإذا كانت البضـاعة تختلف عن حالتها تلك ، فعلى المستلم ان يثبت تحفظاته عن البضـاعة في وصل التسليم ، او على سند الثحن ذاته ، بييان مـا اصـابها من نقص او تلف بشكل محدد ، ويبلغ ذللك للناقل او من يمنله ، امـا عن حق الناقل في اثبـات خـلاف مـا ورد في سند الثحن ، فلـه ان يثبت مـا يخـالف بيانـات سند الثـحن بكل الطرق اذا كـان

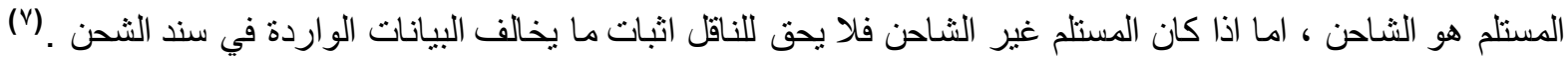


المطلب الثاني- هلاك البضاعة

يقصد بالهلاك زو ال الثـيء ، وهو الحالة المثلى يتحقق الضرر ، حيث يصعب على الناقل منازعة حصـوله ،

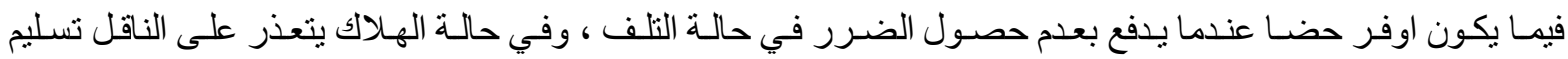

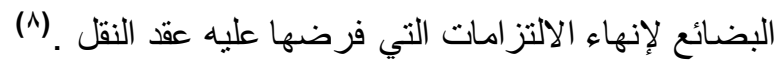

وبقصد بالهلاك في مجال نقل البضائع بتخلف تسليم البضـائع الى صساحب الحق في تسلمها في مكان الوصول ،

وقد يكون الهلاك كليا بتخلف اي تسليم للبضـائع في مكان الوصول وذلك امـا لزوال الكبان المسادي او لسرقتها او لتسليمها لغير صاحب الحق في تسلمهم سواء في مكان الوصول او مكان اخر او يكون هلاكا جزئيـا اذا لحق بأجزاء فقط الامتعة

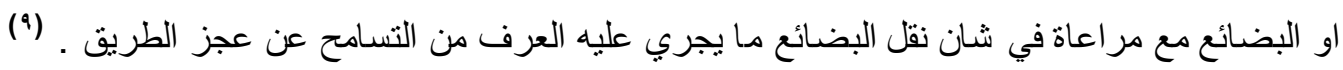

فقد جرى العرق البحري على التسـامح في جز ء معين لا يسـال الناقل عن الهلاك في حدوده وهو مـا يسمى () كئل

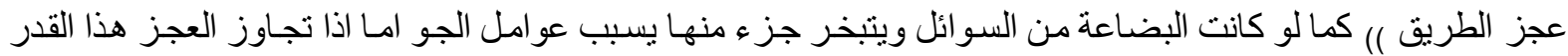
المتسامح فيه فان المسؤولية تخفف عن كاهل الناقل بمقدار النسبة المسموح بها ، ويعوض صـاحب البضـاعة عن الباقي

(1.) فقط

وقد يكون الهلاك ماديا او هلاك حكميا ، فالهلاك المادي كما في حالـة احتر اق البضـائع حكميـا كمـا في حالة عدم

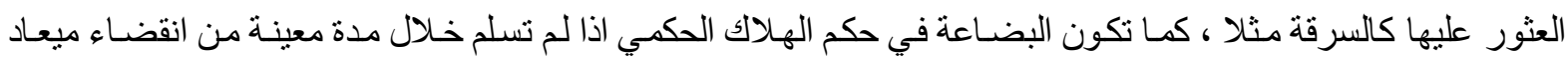
التسليم المتفق عليه ، وميعاد التسليم هو الميعاد المتفق عليه بين الثـاحن و الناقل علا تسليم البضاعة. (1')

\section{المبمث الثاني- اساس هسؤولية الناقل البمري}

تختلف التشـريعات فيمـا بينها حـول اسـاس مسؤولية ناقل البضـائع ، في التشريعات اللاتينيـة تتجها نحوه جعل مسؤولية الناقل البحري مسؤولية تعاقديـة تقوم على افتر اض المسؤولية اي الاخـلال بالتزام لتحقيق غايـة او نتيجة ، بينمـا

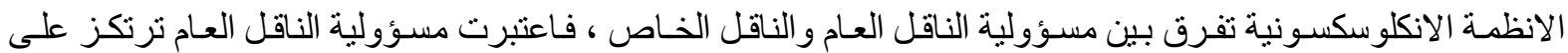

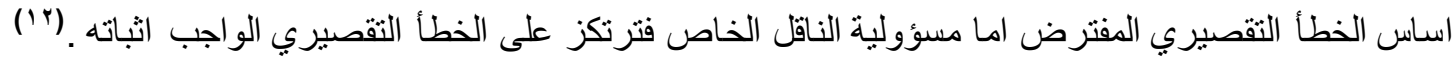
لذا سنتناول في هذا المبحث في خمسة مطالب نخصص المطلب الاول لمسؤولية الناقل البحري في التشريعات و الاتفاقيات المقارنة ، وفي المطلب الثناني لأسساس المسؤولية في القانون العر اقي ، وفي المطلب الثالث نتحدث عن فكرة

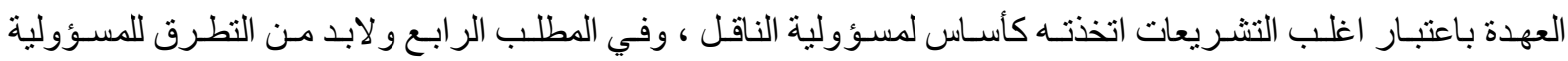
التقصيرية ، وأخيرا سيكون الحديث عن مسؤولية الثاحن تجاه الناقل في المطلب الخامس . المطلب الاول- اسلس مسؤولية الناقل البحري في التشريعات والاتفاقيات المقارنة بخصوص قو اعد اتفاقية هـامبور غ لسنة 9 ( فأنهـا تقيم مسؤولية الناقل البحري عن تلف البضـاعة وهلاكهـا على اساس الخطأ المفترض حسبما جـاء في المـادة الخامسـة فقرة اولى منها حيث نصت على على أنه (ر يكون الناقل مسؤو لا عن الضرر الناثـيء عن هـلاك البضـائع أو تلفها وكذللك الضرر الناشيء عن التأخير في تسليمها أذا كان الحسادث الذي تسبب في الهلاك أو التلف أو التـأخير قد وقع أثنـاء وجود البضـائع في عهدة الناقل على النحو المشـار اليهله في المسادة

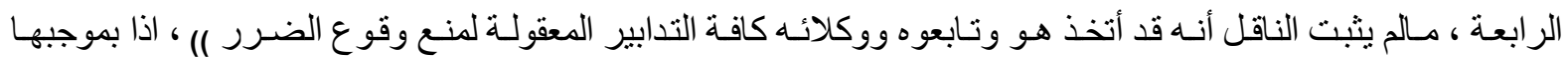
يكون الناقل البحري مسئو لا عن الاضر ار اللاحقة بالبضائع اثناء وجودهـا في عهدته دون ان بلزم المتضرر بإقامة الدليل 
على خطلا الناقل ، لكن للناقل نفي قرينـة الخطأ ودفع مسؤوليته بإثبـات اتخـاذ كافة التدابير المعقولتة لمنع الضرر ، اي ان

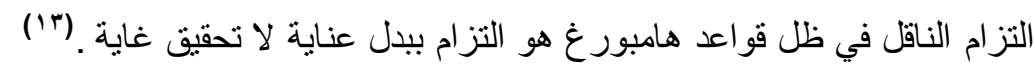

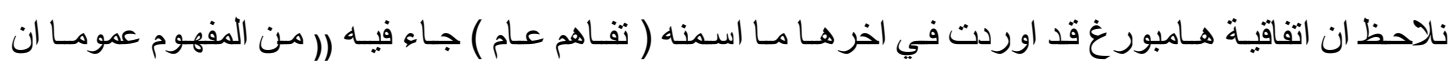

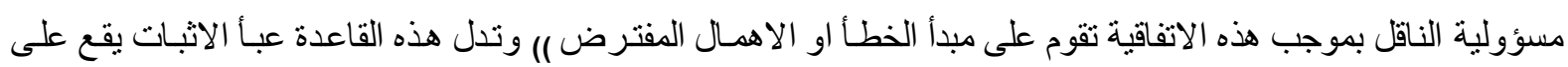

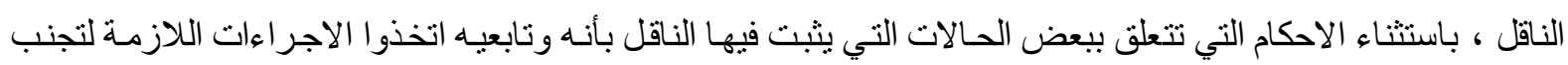
حدوث الضرر .

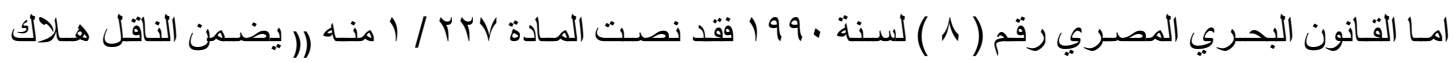
البضـائع وتلفهـا اذا حلث الهـلاك او التلف في المدة بين تسلم الناقل البضـائع في مينـاء الثـحن ، وبين قيامـة في مينـاء

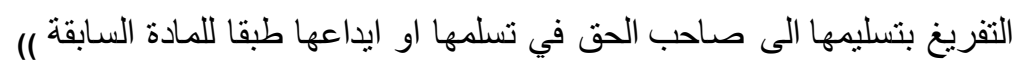

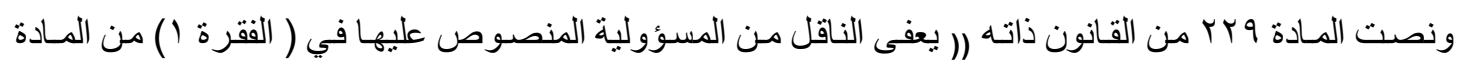

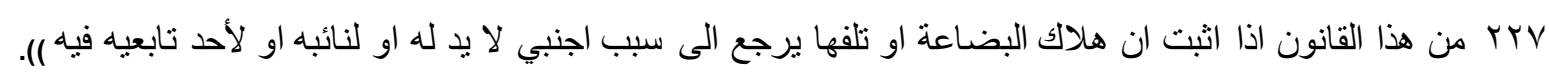

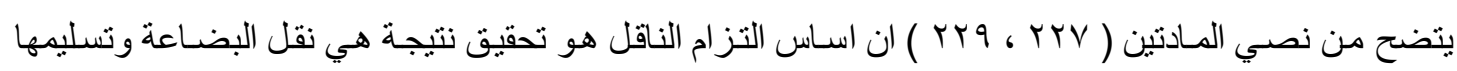

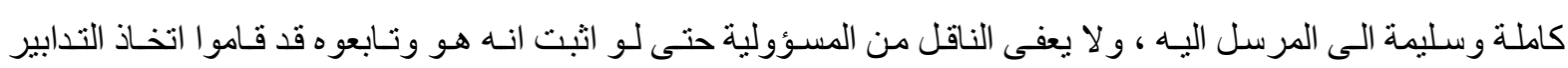

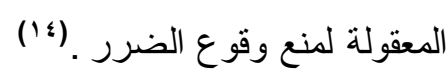
وبالتالي فان المضرور غير ملزم بإقامـة الدليل على الخطأ المرتكب من الناقل ، و إنما يكفيه اثبـات ان الناقل لم

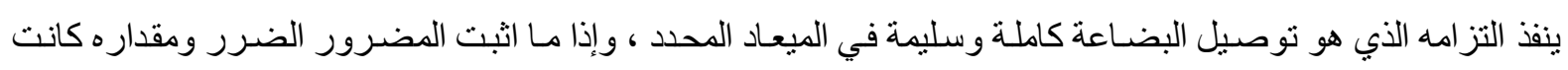

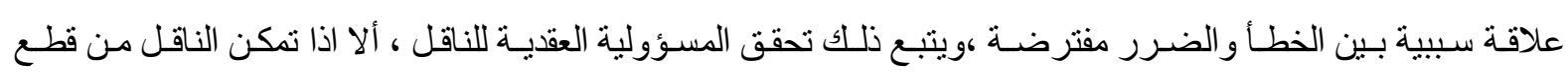

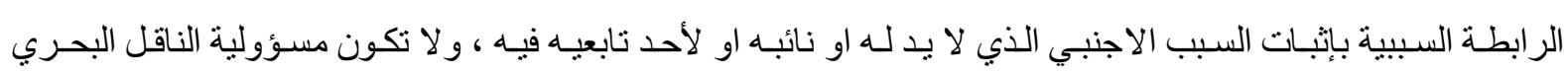

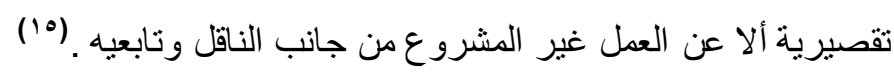
نلاحظ ممـا تقدم ان القانون المصري يقيم مسؤولية الناقل البحري ايضـا على اسـاس الخطـأ المفترض كمـا هـو

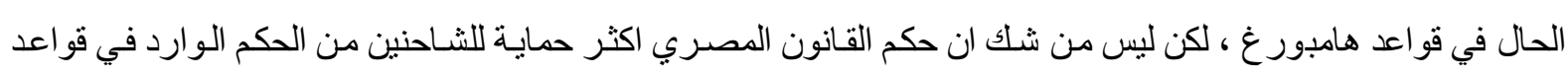

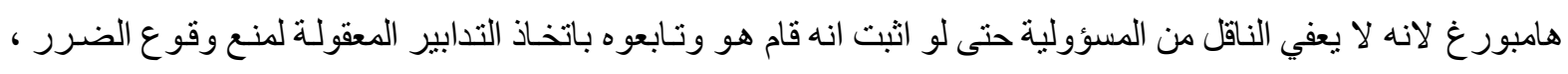

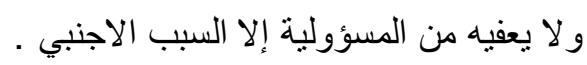

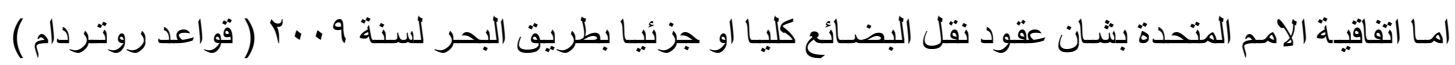

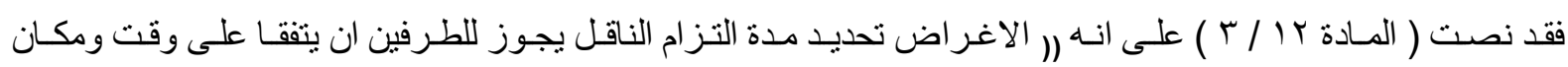
استلام البضاعة وتسليمها ولكن يكون اب حكم في عقد النقل باطني عندما ينص على : أ. ان يكون وقت تسلم البضائع لاحقا لبدء تحميلها الاولى بمقتضى عقد النقل او ب. ان يكون وقت تسليم البضائع سابقا لإتمام تفريغها النهائي بمقتضى عقد النقل ) )

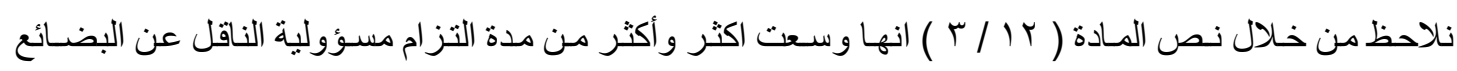

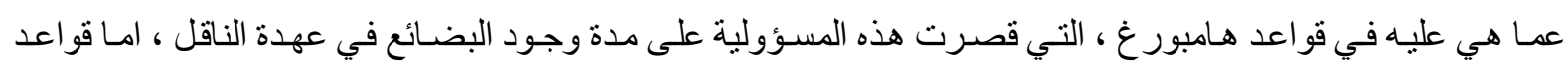


روتردام فأرجعت هذه المدة الى ار ادة طرفي عقد النقل اي الناقل والثـاحن ، لذا يمكن القول ان اتفاقيـة روتردام اكتر عدالة من اتفاقية هامبور غ اذ جاءت لصالح الثاحنين .

امـا المادة ( V / V ) من قو اعد روتردام فقد نصت (ر يكون الناقل مسئو لا عن هلاك البضـائع او تلفها ، وكذلك التأخر في التسليم ، اذا اثبت المطلب ان الهلاك او التلف او التأخر ، او الحدث او الظرف الذي تسبب او اسهم فيه ، قد

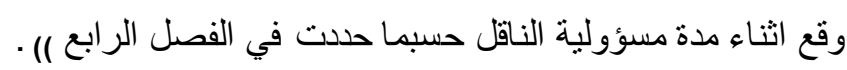

يتضح لنا من المـادة ( / V / ) ان اتفاقية روتردام اقامت مسؤولية الناقل عن هلاك البضـاعة او تلفها اذا اثبت

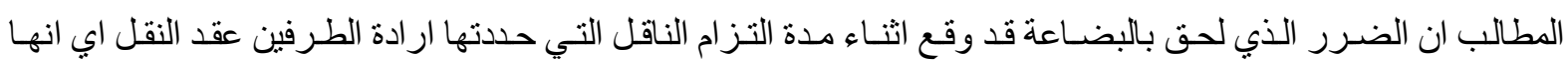

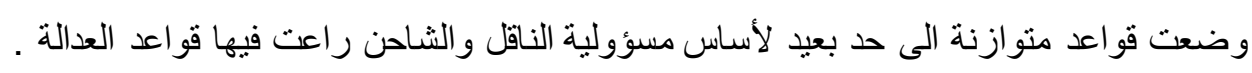

اما المادة ( V / Y ) فقد نصت (ر يعفى الناقل من كامل مسؤوليته التي تقتضي بها الفقرة ا من هذه المـادة او

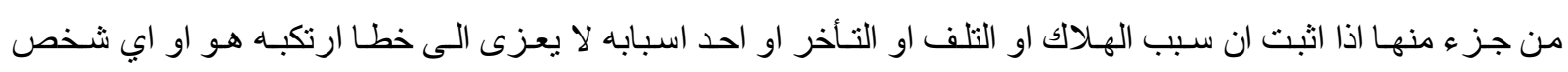

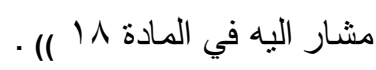

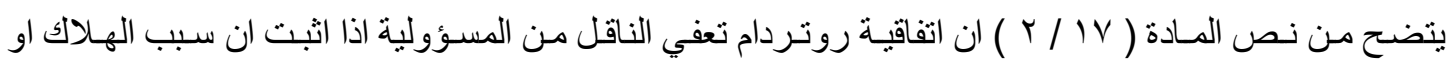

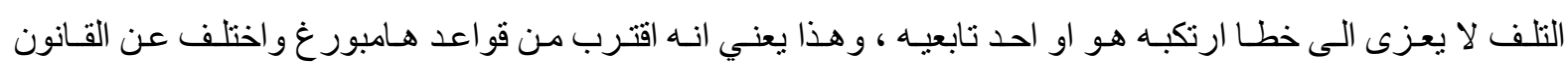
المصري التي لا تعفي الناقل من المسؤولية إلا عن السبب الاجنبي.

نلاحظ ان كلا الاتفاقيتين المذكورتين يؤخذ عليها عدم النص على حرمان الناقل من ميزة تحديد المسؤولية اذا

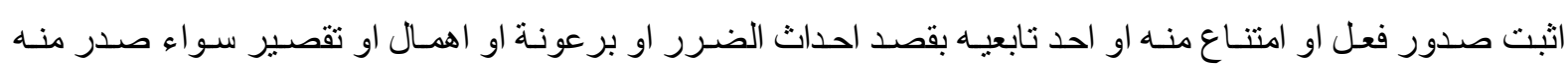
شخصيا او من احد تابعيه الامر الذي يضعف من فعالية الحكم ، في حين ان اغلب الاخطاء تقع من التابعين وليس الناقل

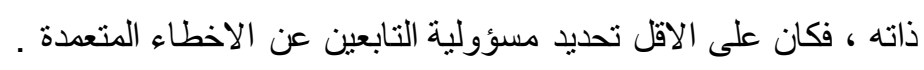

المطلب الثاني- اساس مسؤولية الناقل البحري في التقنين العراقي

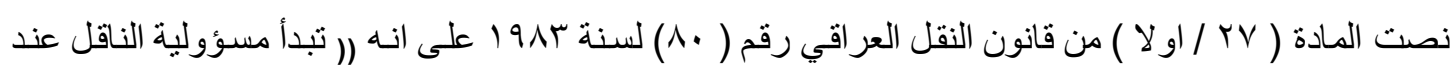

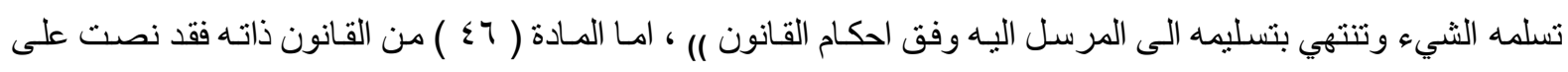

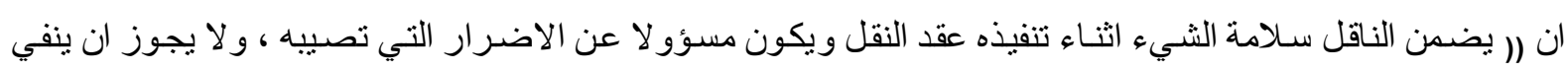

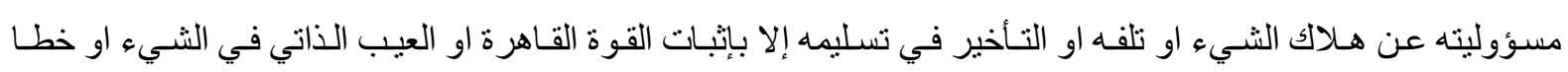

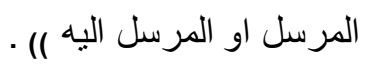

يتضح من النصين المتقدمين ان مسؤولية الناقل البحري وفق القانون العر اقي تبدأ عند نسلمه الثـيء وتنتهي

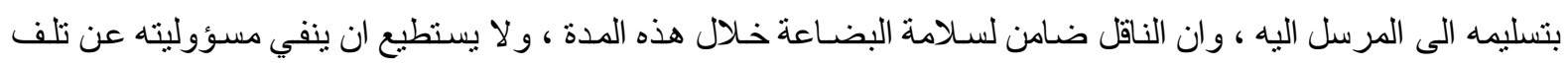

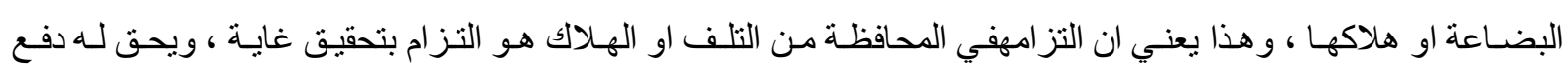

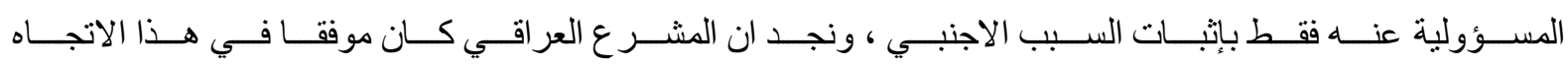

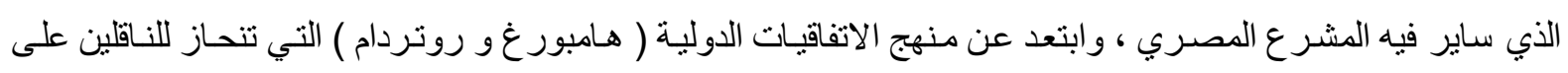




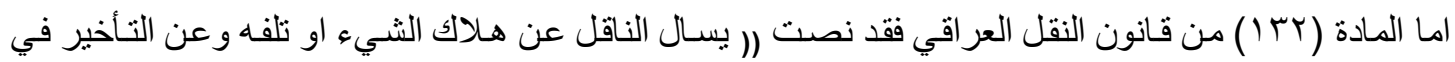

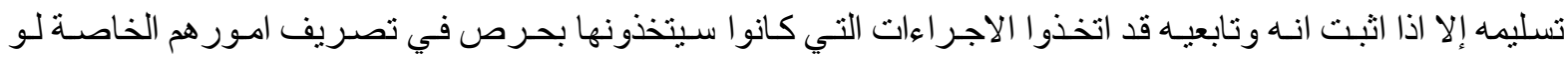

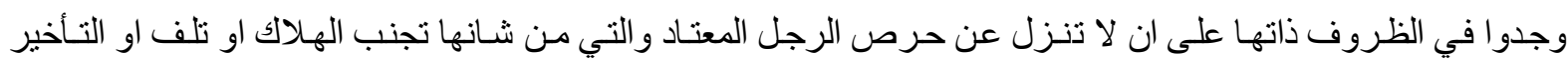
وتفادي نتائجه ) .

نلاحظ ان الــادة الاخيرة تتعـارض مـع الــادة ( 7؟ ) من قـانون ذاته اذ انها تجعل القانون العر اقي يقترب من

نص المادة الخامسة الفقرة الاولى من اتفاقيـة هـامبورغ التي تعفي الناقل من المسؤولية اذا اثبت انهه هو وتابعيه قد اتخذوا

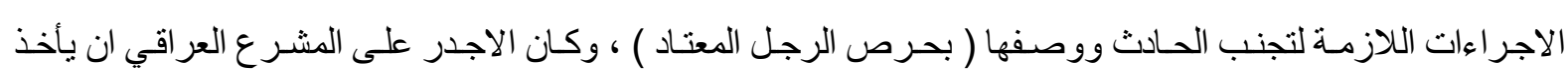

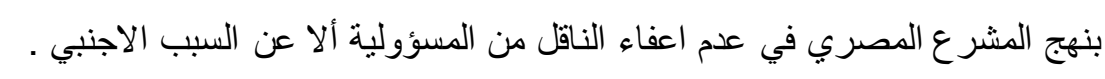

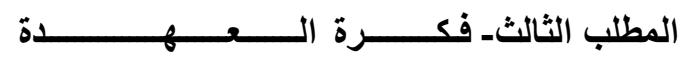
ان هذا التصور للأساس المسؤولية يشمل مفهوم ما طرحه البعض من ان مسؤولية الناقل ، سواء في نقل الثيء

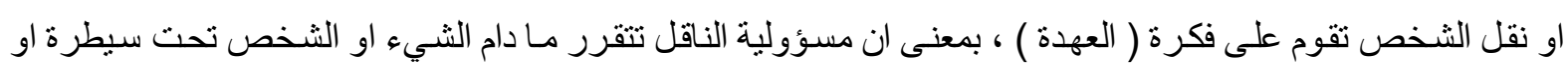

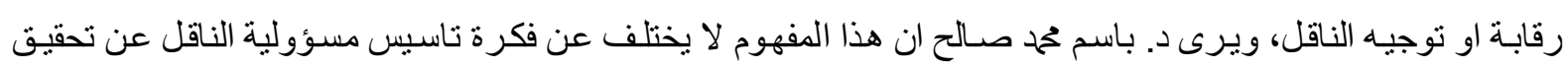

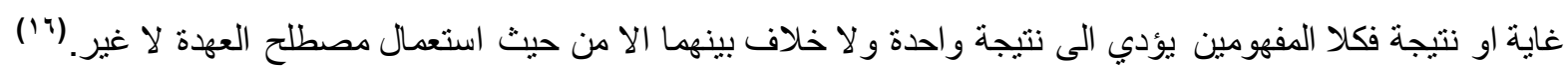
كما اعتمدت اتفاقية هامبور غي فحديد نطاق التزام الناقل بضمان سـلامة البضـاعة من التلف او الهـلاك بفكرة

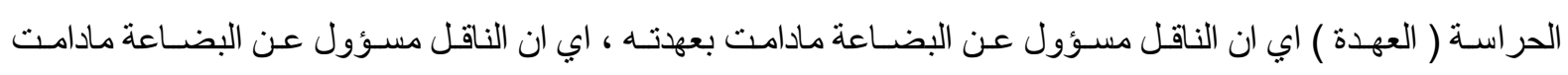

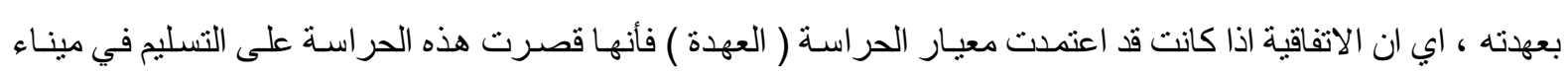

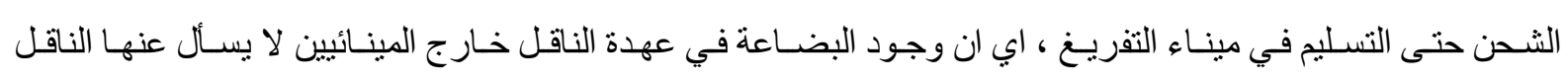

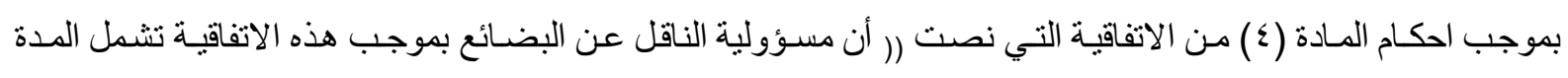

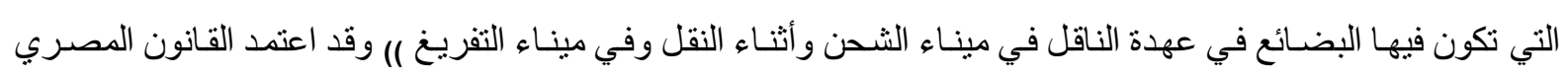

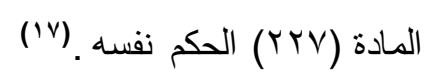

لكننا من خلال نص المادة (ع ) من اتفاقية هـامبور غ نرى أن مصطلح (و أثناء النقل) تشمل مسؤولية الناقل عن البضاعة خارج المينائيين ايضا ، اي تشمل مسؤوليته عن البضاعة في ميناء الثحن ومينـاء التفريخ و أثناء الطريق ، فكان

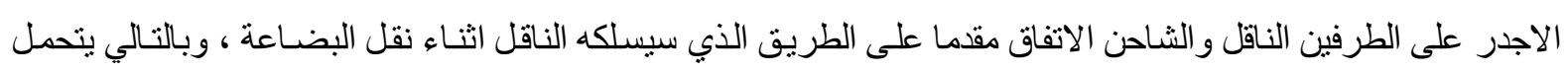

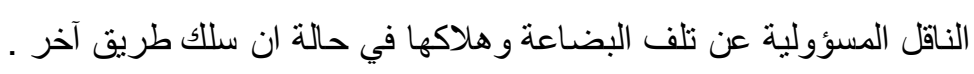

المطلب الر ابع-مسؤولية الناقل التقصيرية

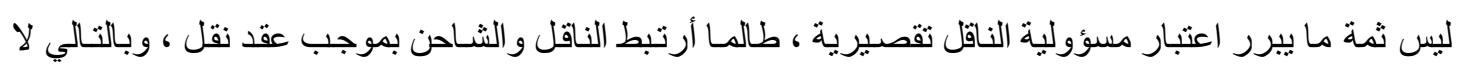

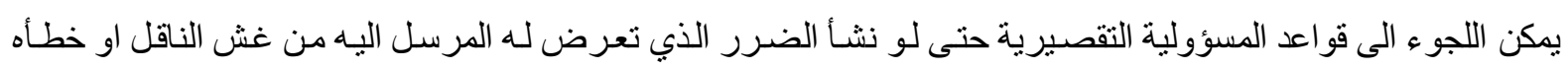

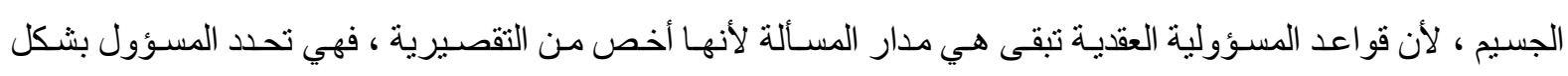

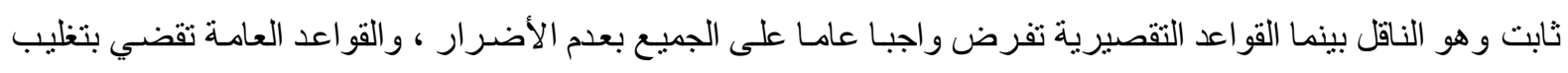

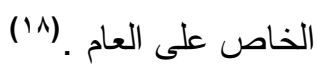

فالمسؤولية تكون على هذا الأساس عقدية ، تقوم بمناسبة الإخـال بتنفيذ الالتزام الذي القاه على عاتقه عقد

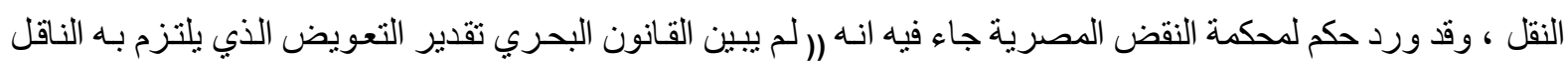


، لما كان ذلك فأنه يتعين تقدير التعويض وفقا ل القو اعد العامـة الواردة في القانون المدني في شـأن المسؤولية التعاقديـة

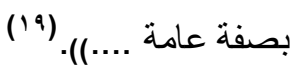

يتبين من حكم محكمـة النقض المصرية أنها اعتبرت مسؤولية الناقل البحري مسؤولية عقديـة تخضـع للقو اعد

$$
\text { العامة في القانون المدني . }
$$

امسا بخصوص القـانون العر اقي فـأن القانون المدني العر اقي قد اشـار الى صسورة من صسور المسؤولية الثيئية التي تتخذ صور عدة منها مسؤولية من يتولى حراسة الآت ميكانيكية او أثباء تتطلب حر استها عناية خاصـة عما تحدثـه

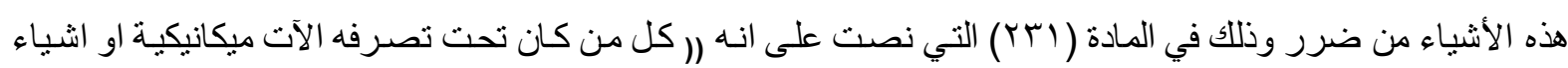

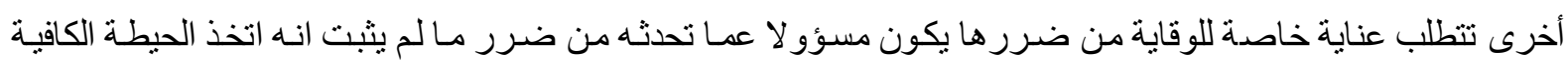

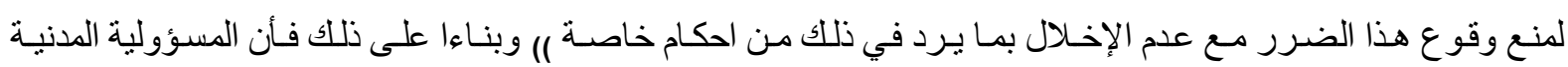

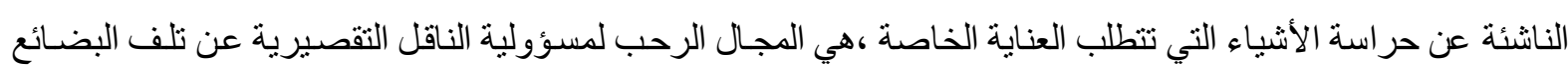

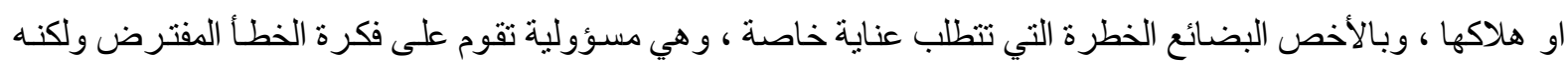

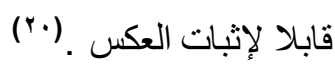

\section{المطلب الخامس- مسؤولية الثشاحن تجاه الناقل}

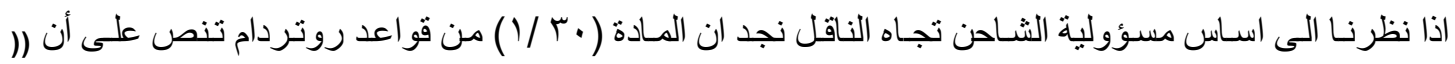

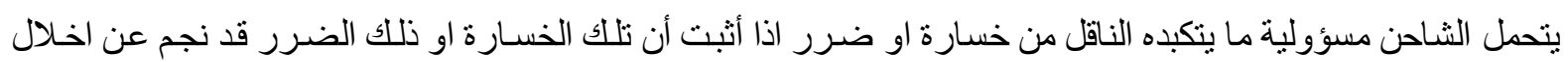

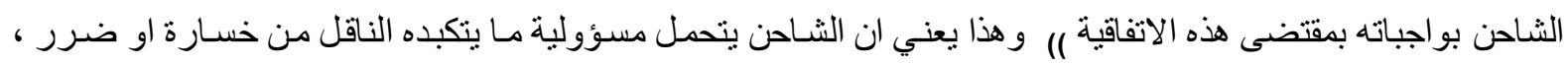

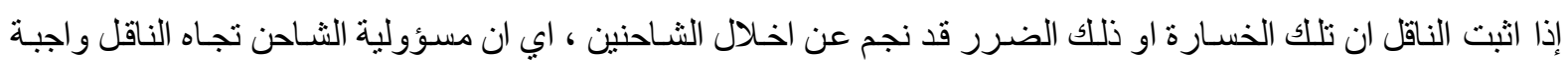

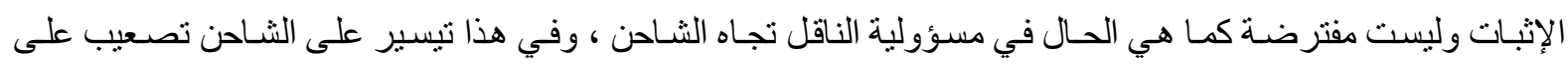

اما الفقرة الثانية من المادة (• ب) من اتفاقية روتردام فأنها تعفي الشـاحن من المسؤولية اذا كان سبب الخسـارة او

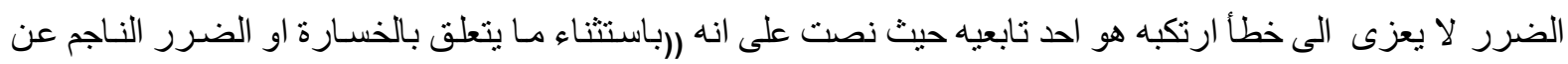

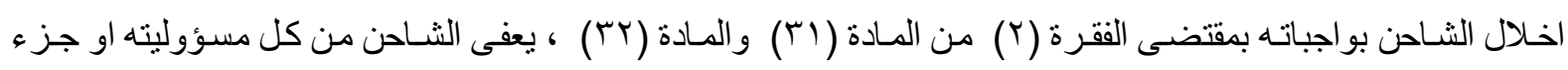

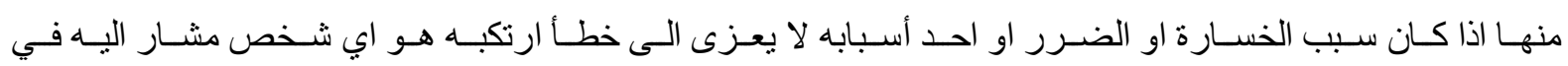

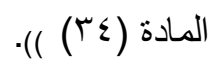

امـا في ظل احكام القانون العر اقي فأن الشاحن يجوز لـه أن يعفي نفسه من المسؤولية العقديـة تجـاه الناقل البحري

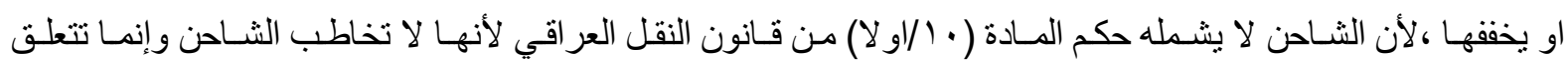

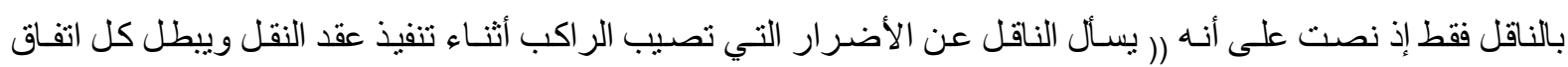

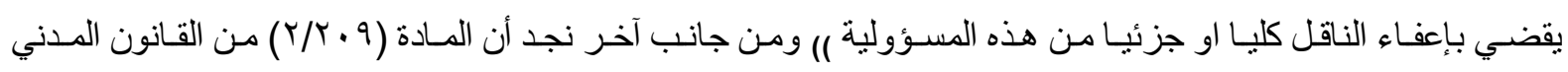
العر اقي تجيز للشاحن ان يعفي نفسه من المسؤولية او تخففهـا إذ نصت (وبذللك يجوز الاتفاق على اعفاء المدين من كل هن

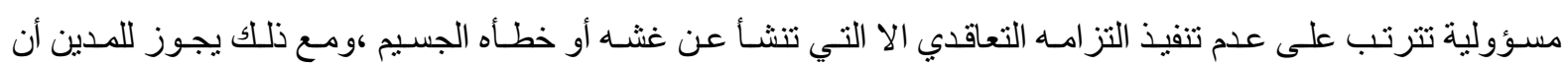

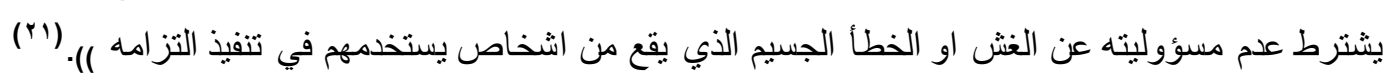




\section{المبمث الثالث- إعفاء الناقل البمرى من المسؤولية عن تلف البضاعة او هلاكها}

يكون للناقل في بعض الحالات في بعض الحالات الحق في دفع المسؤولية والإعفاء منها في حالة إثباته أن تلف البضاعة أو هلاكها يرجع الى عدة حالات ،و هذه الحالات تختلف بـاختلاف التشريعات فقي القانون العر اقي يستطيع الناقل

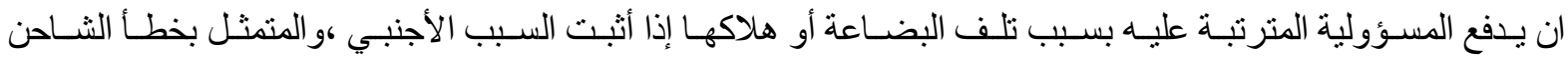
(المرسل) أو عيب ذاتي في البضـاعة أو خطأ الغير أو قوة قاهرة ،امـا القانون البحري المصـري فقد نص على على حسالات

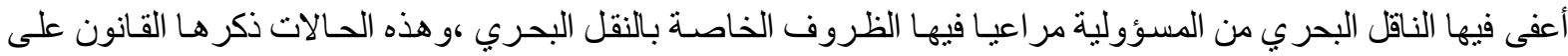
سبيل الحصـر ،وهي حـالات تعمد الثـاحن ذكر بيانـات غير صحيحة في سـند الثـحن ، وحالـة النقل على سطح السفينة

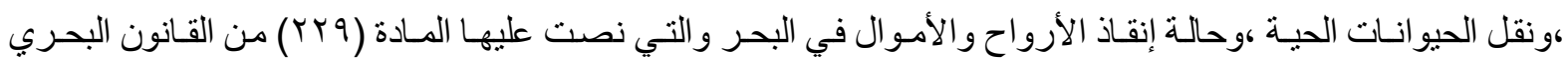
المصري لسنة . 199 ،وبقدر تعلق الأمر بالقانون العر اقي فسنقتصر على ذكر الحالات المشتركة بين القانونين ،وذلك ولك

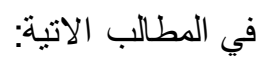
المطلب الأول : خطأ الشاحن (المرسل) . المطلب الثناني :القوة القاهرة. المطلب الثلث :العيب الذاتي في البضاعة .

\section{المطلب الأول- خطأ الشاحن ( المرسل )}

يستطيع الناقل دفع المسؤولية عنه إذا أثبت أن الضـرر اللاحق بالبضـاعة ناثـيء عن خطـأ الثـاحن كعدم أحكام

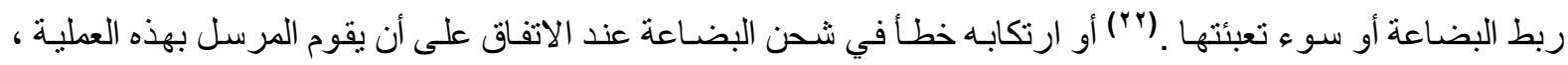

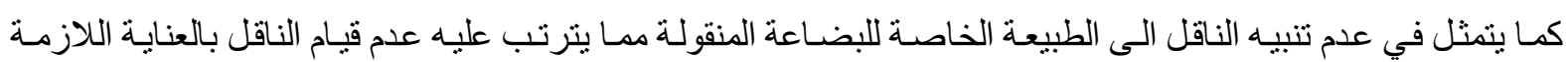
اللمحافظة عليها . (r)

فمن حيث المبدأ يوجد التزام رئيسي مفروض على الشـاحن بأن يعلم ويخطر الناقل البحري عن الصفة الخطرة

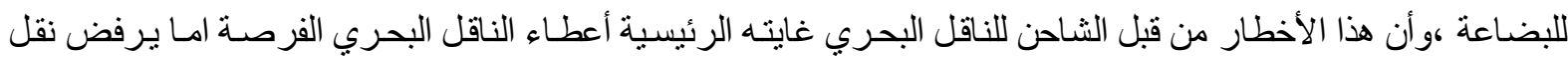

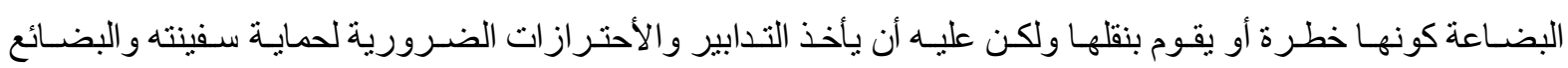
والحمولات الأخرى التي عليها من الخطر . (r)

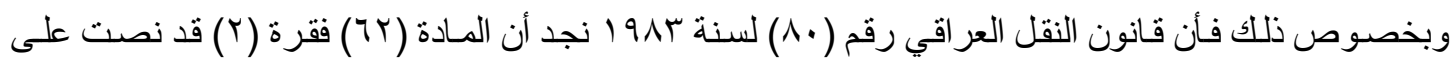

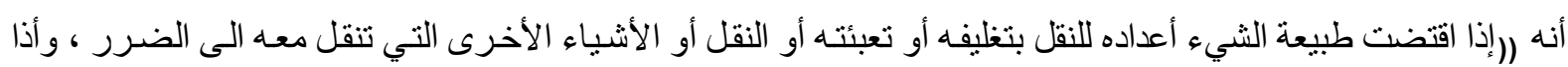

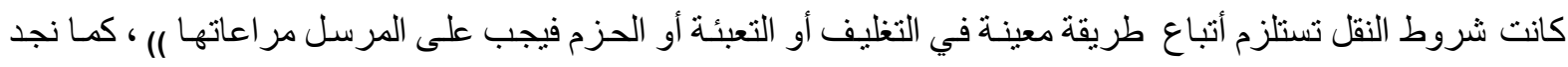

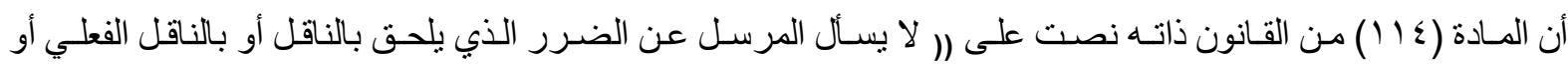

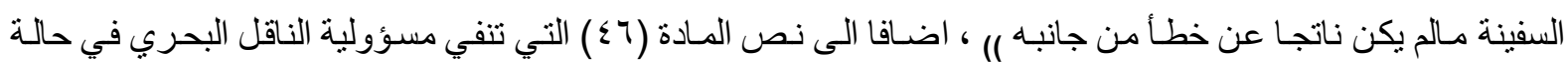
خطأ المرسل أي الشاحن . (ro)

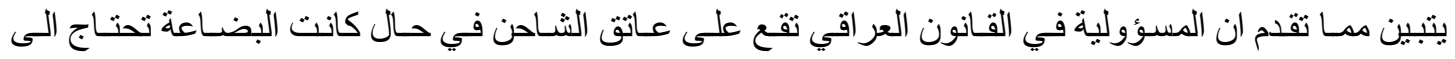
التعبئة أو التغليف ولم يقم الثـاحن بمر اعـاة ذلك ممـا ادى الى تلف البضـاعة او هلاكها ، كمـا لاتقتصر مسؤولية الثـاحن

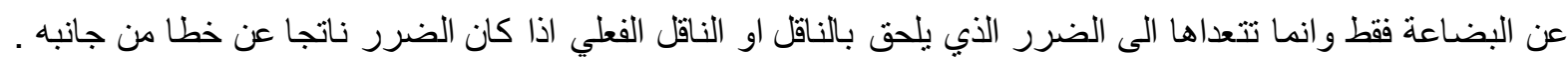


وبخصوص معاهدة هامبور غ فأن المـادة (1/0) أعطت للناقل الحق في التتصل من المسؤولية في حالـة تلف البضاعة أو هلاكها إذا أسنطاع الناقل أثبـات أنه قد أتخذ هو أو مستخدموه أو وكلانئه جميع ماكسان من المعقول أتخاذه من تدابير لتجنب الحادث وتبعاته . (r)

يعتبر من قبيل خطأ الشاحن تعده ذكر بيانات غير صحيحة في سند الثحن عن طبيعة البضـائع أو قيمتها ، فلا

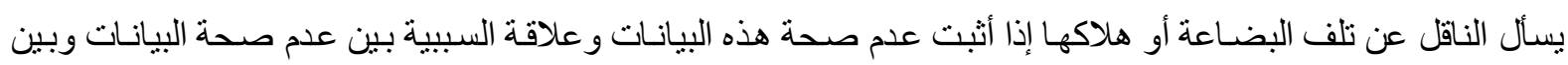

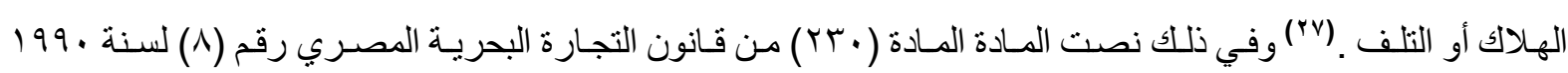

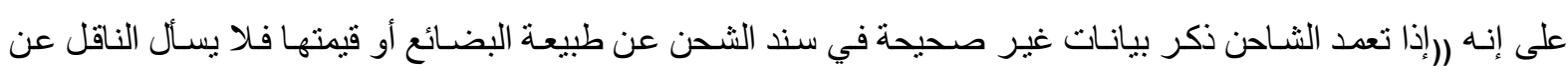

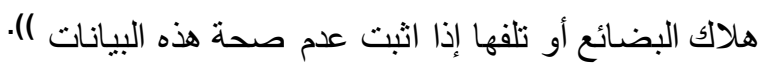

فـاذا قدم الثـاحن عمدا بيانـات غير صحيحة عن طبيعة البضـاعة المشحونة أو قيمتها ، فـأن الجزاء هو أعفـاء الناقل من المسؤولية أيا كان سبب الضرر الذي لحق بالبضاعة ، ويترتب هذا الجزاء ولو لم يكن للبيان غير الصحيح أثرا

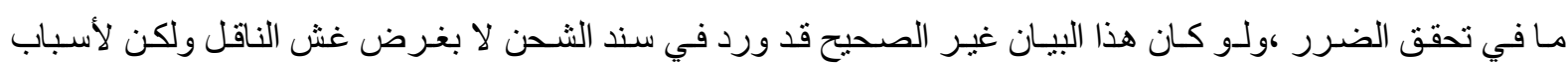

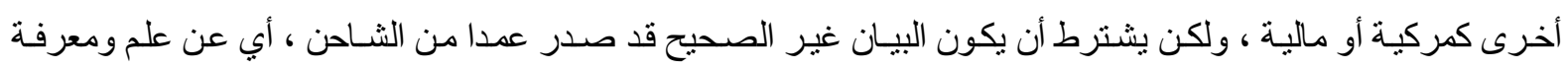

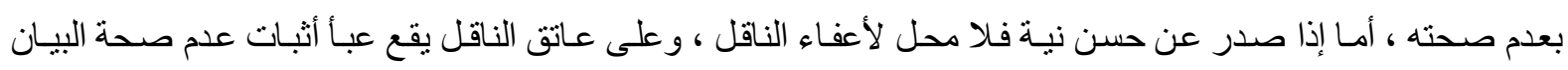

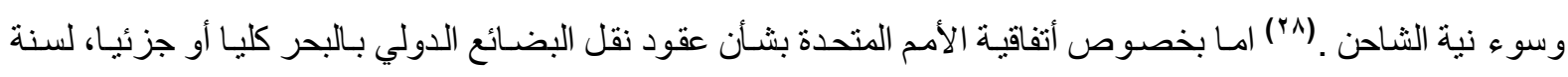

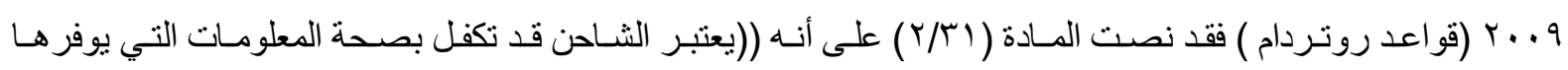
بمقضى الفقرة ( من هذه المادة وقت تلقي الناقل تللك المعلومات من خسارة أو ضرد ) ) . ويتضح من نص هذه المـادة أن الثـاحن ضـامنا لصحة المعلومـات التي يقدمها الى الناقل لأعداد تفاصبل العقد ،

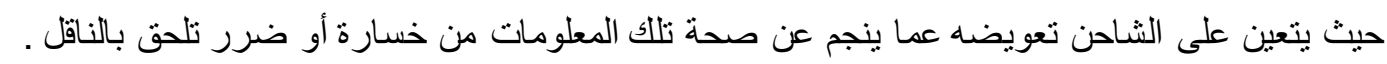

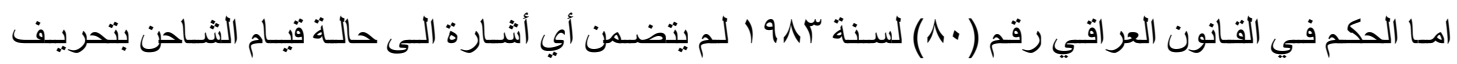

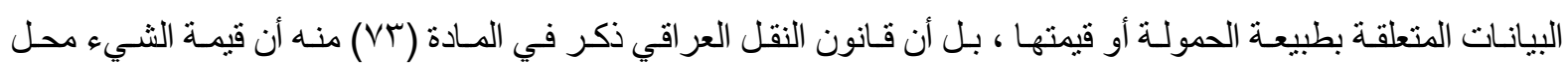

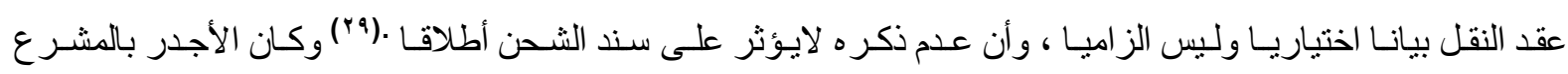

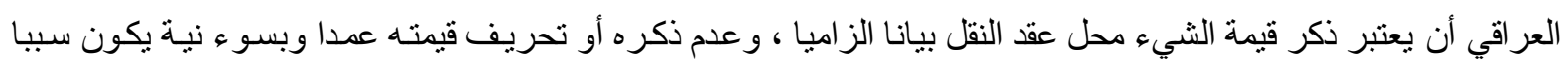

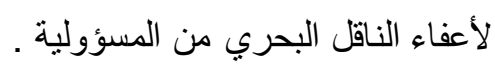

المطلب الثاني- القوة القاهرة يقصد بالقوة القاهرة كل حاثث لا يمكن توقعه و لا يمكن دفحهه ، وليس للناقل دخل في حدوثه مما يجعل التزام

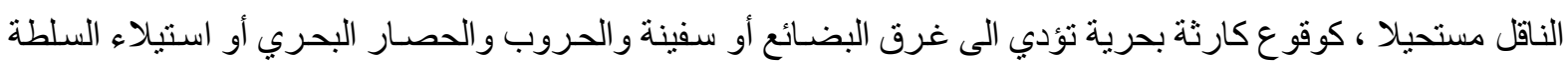

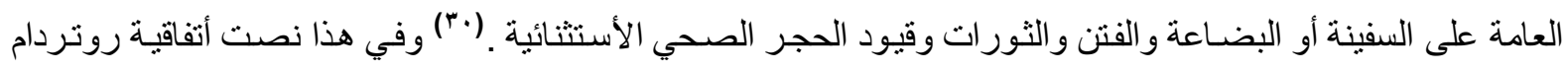

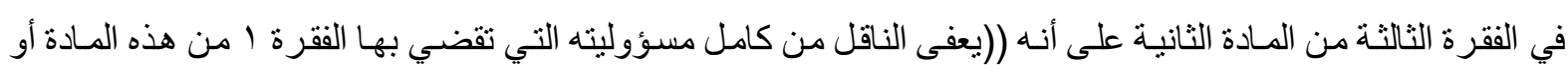

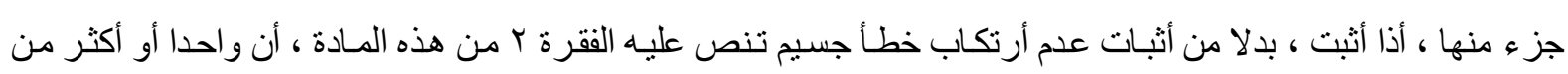

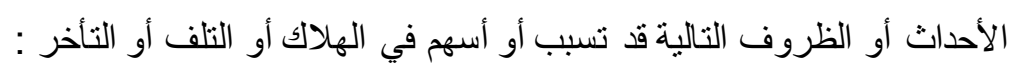

$$
\text { أ. أ. القضاء و القدر. }
$$




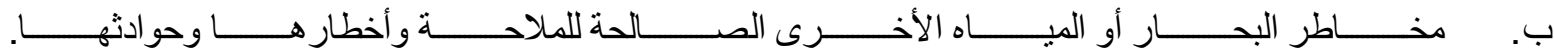

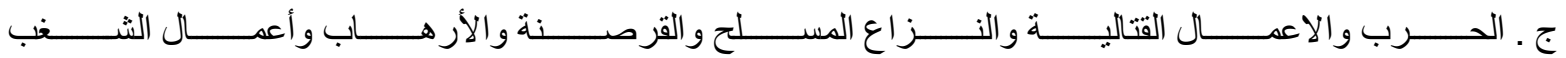
و الأضطر ابات الأهلية .

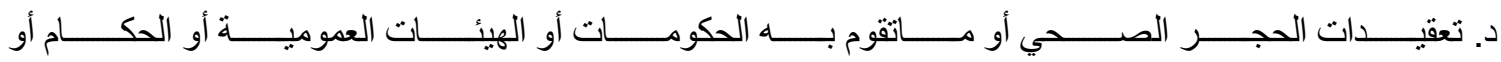

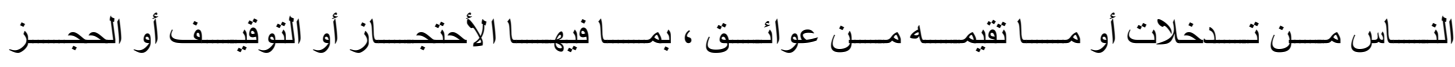
الذي لا يعزى الى الناقل أو أي شخص مشار اليه في المادة 11 ـ ـ

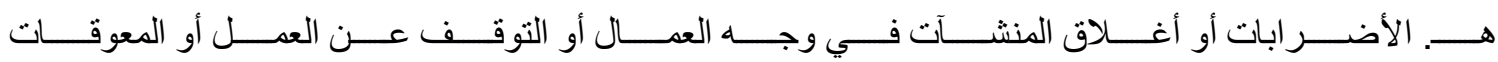

$$
\text { و. نشوب حريق على السفينة . }
$$

ز. وجود عيوب خفية يتعذر أكتشافها ببذل العناية الواجبة .

وبـالرجوع الى القانون العر اقي نجد المـادة (ع ب) من فانون النقل العر اقي نصـت على أعفاء الناقل البحري مـن

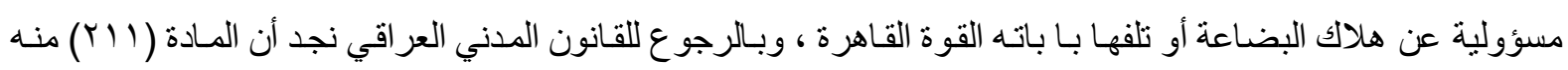

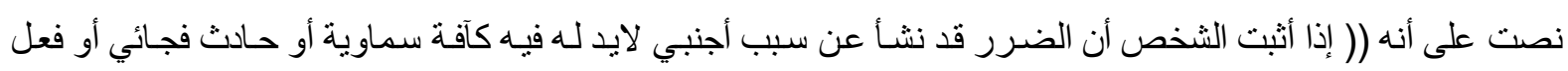

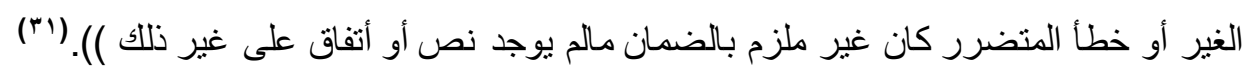
و لايعتبر قوة قاهرة أنفجار وسـائط النقل أو احتراقها أو خروجها عن القضبان التي تسبر عليها أو تصـادمها ،

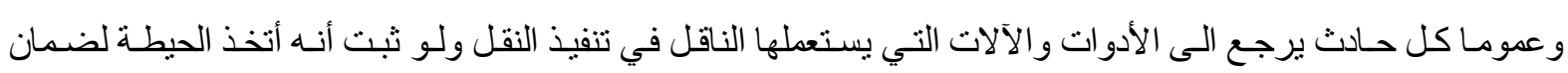

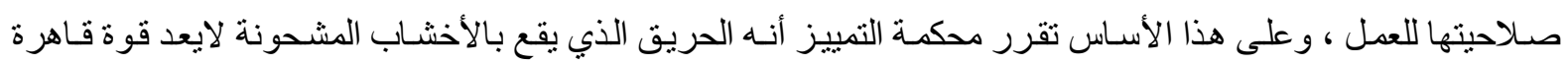

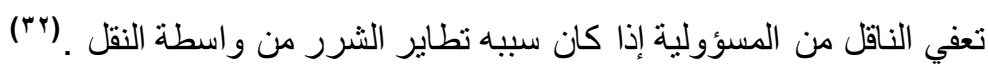
في حين نلاحظ أن قو اعد روتردام أعتبرت الحريق الذي ينشب في السفينة ضمن القوة القاهرة التي تعفي الناقل

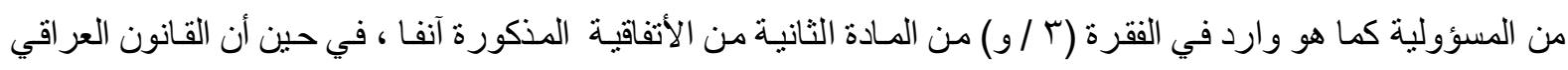

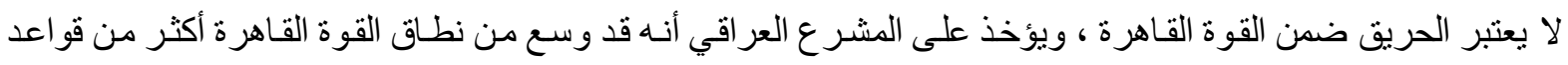

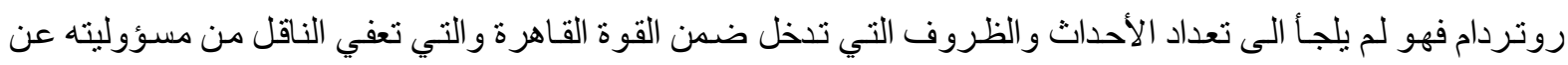

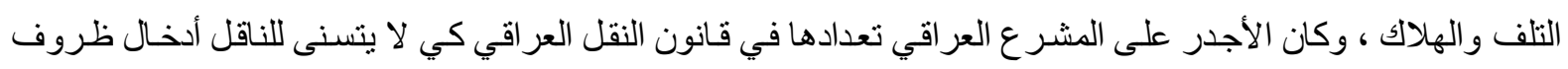

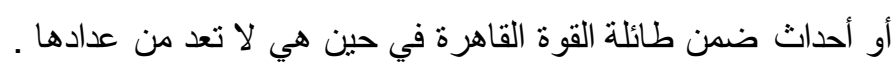

أما بالنسبة لقو اعد هامبور غ فقد واجهت حالة الحريق بنص خـاص في المـادة الخامسـة فقرة (ع ) ، بموجبه يسـأل الناقل في حالة الحريق بشرط أن يثبت المدعي أن الحريق نشـأ عن خطأ أو أهمال من جانب الناقل أو تابعيه أو وكلائهه ، وبالتالي لا يكون خطأ الناقل البحري مفترضا في حالة الحريق وأنما يتعبن على المضرور أنبات أرتكاب الناقل أو تابعيه

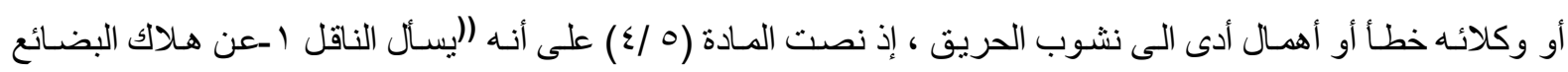

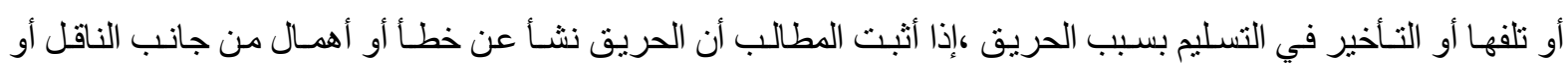
مستخدميه أو وكلائه ). 
هذا الأستثناء على الخطأ المفترض ليس مستسـاغا ، فمن المنطقي وضع عبئ أثبات و اقعـة فنية منشئة للضرر على عاتق الناقل ، لأنـه في مركز أفضل من مركز الثـاحن لأثبات أنتفاء خطـأه أزاء الحريق ، بالأضـافة الى أن الناقل يوجد في السفينة بنفسـه أو عن طريق تابعيه ، فيكون شـاهدا على الحادث دون الثـاحن ، ولقطع السبيل على كل محاولـة

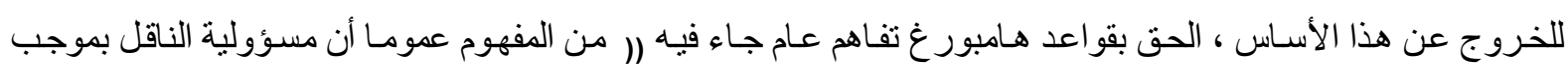

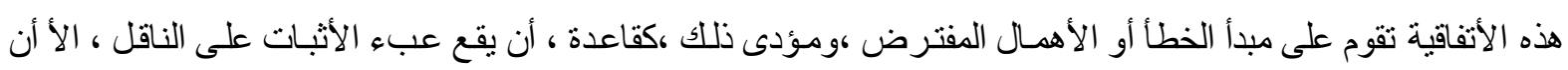

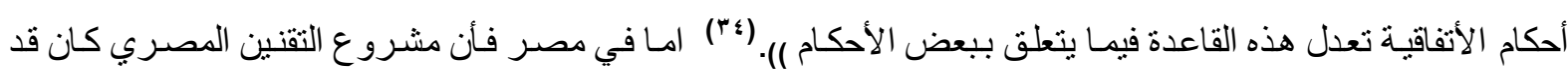

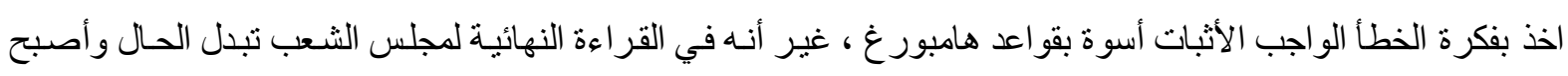

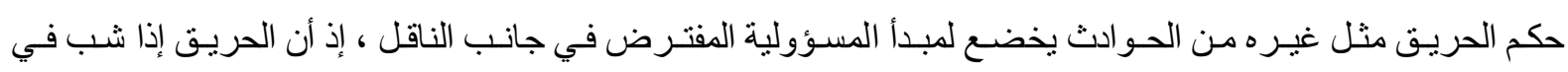

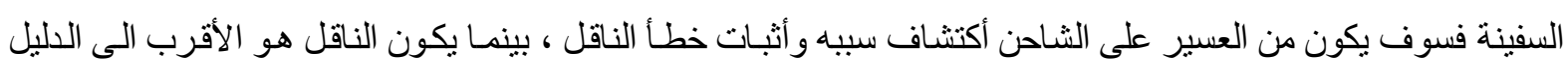

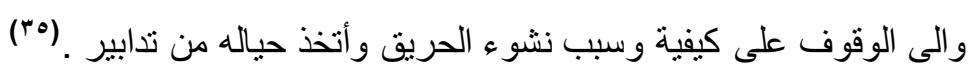

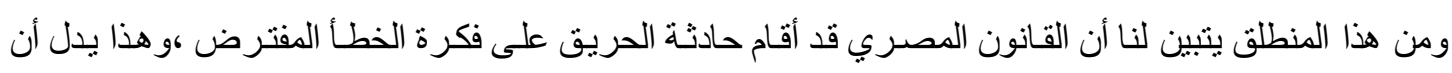

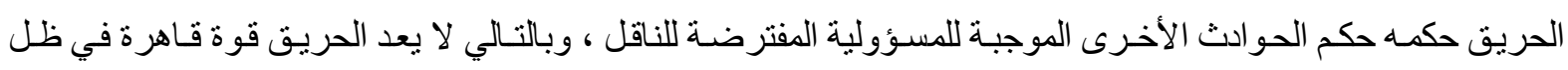
القانون المصري ، بخلاف أتفاقية هامبور غ التي تعد الحريق قوة قاهرة في حال عدم قدرة الثـاحن على أثبـات خطأ الناقل

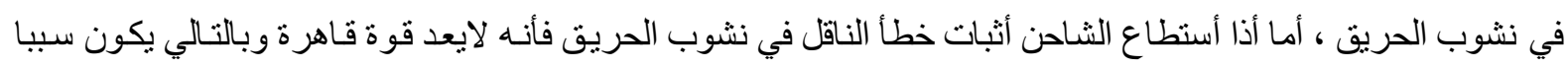

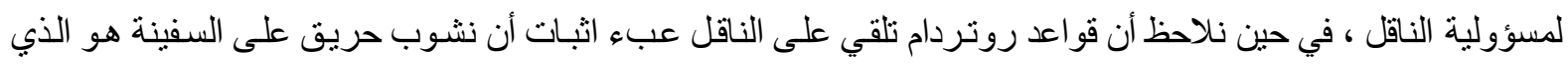

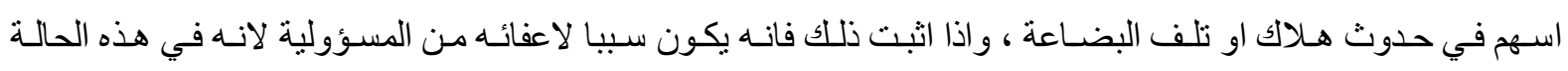

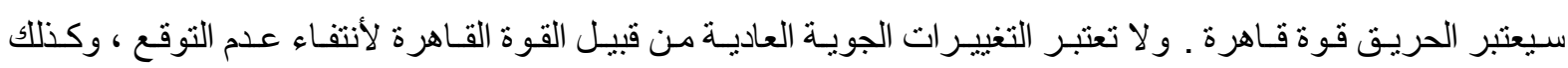

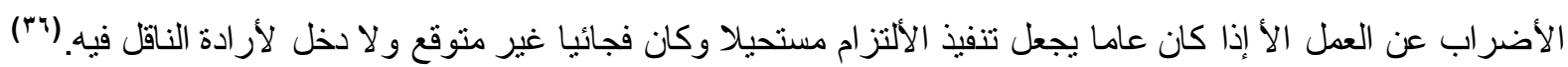
وتطبيقا لنلك حكم بانـه لا يعتبر من قبيل القوة القاهرة الجو السيء الذي صسادف السفينة ، متى كـان لا يجـاوز

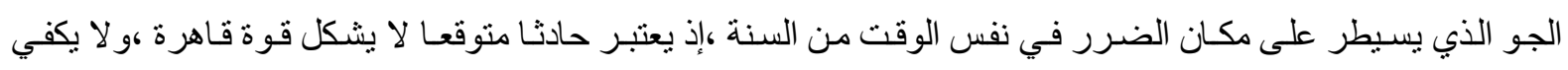
للتمسك بـالقوة القاهرة أن يكون سبب الحادث غير معروف ،بل على الناقل أن يثبت أن حادثا غير ممكن توقعها وتفاديـا

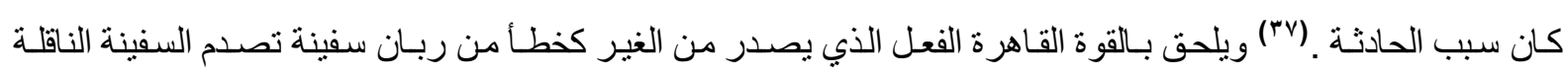

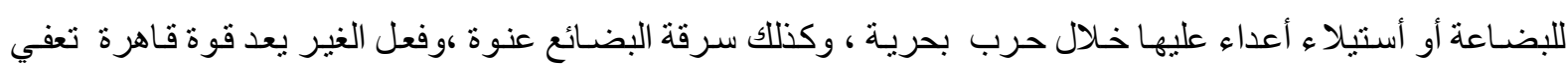

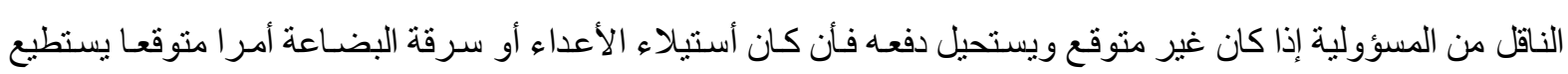

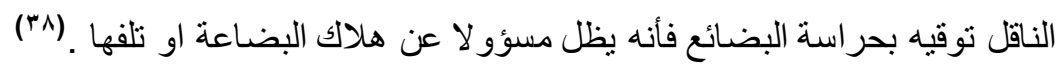
ويقصد بالغير في هذا الصدد كل شخص لا يكون الناقل مسؤو لا عن أفعاله ، فلا يعد من الغير ( تابعوا الناقل ) و على ذللك لا يكون الناقل مسؤو لا عن الضـرر الذي يلحق البضـاعة بسبب تصسادم السفينة التي تحمل البضـاعة مـع سفينة

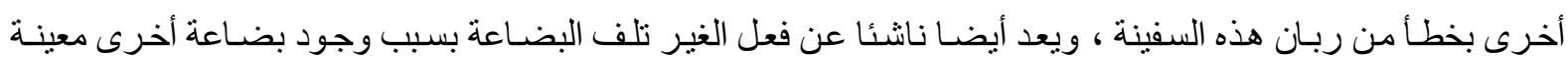

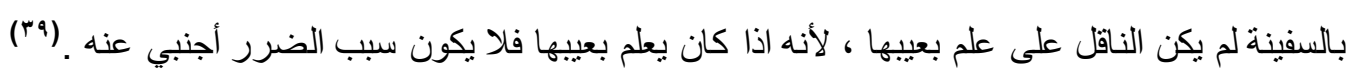
ونلاحظ أنه ليس هناك حاجة الى التفرقة بين القوة القاهرة وفعل الغير ، أذ أن فعل الغير أذا كان فجائيـا أو غير

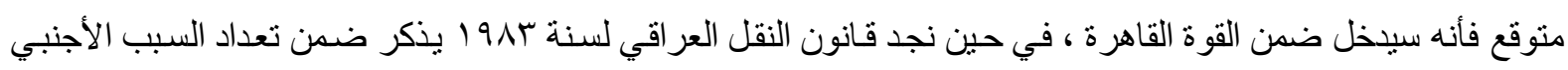


فعل الغير بأعتباره سببا مستقلا بذانه ، في حين نرى أنه يعتبر ضمن القوة القاهرة وكـان من الأجدر دمجه معها ، لكن يجب أن تتوفر في هذا الفعل شروط القوة القاهرة وهي (عدم توقعه وعدم أمكانية دفعه) حتى لا يكون الناقل مسؤو لا عنه المطلب الثالثـ- العيب الذاتي في البضاعة

يقصد به أي سبب ناشىعن طبيعة البضاعة الداخلية يؤدي الى هلاكها أو تلفها دون تدخل من الناقل ، بمعنى

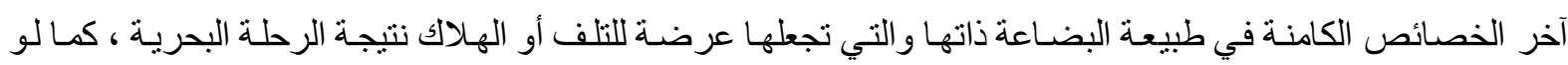
كانت البضاعة تتلف نتيجة الحرارة أو التعرض للرطوبـة ، أذ أن مثل هذا الضـرر سببه أجنبيا عن الناقل فلم يسأل عنه ،

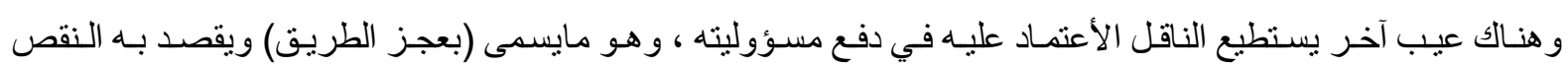

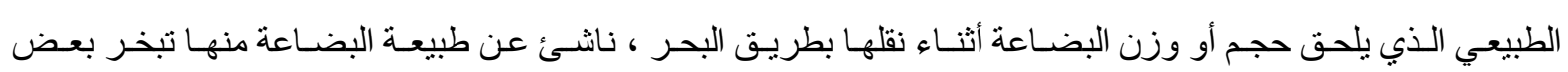

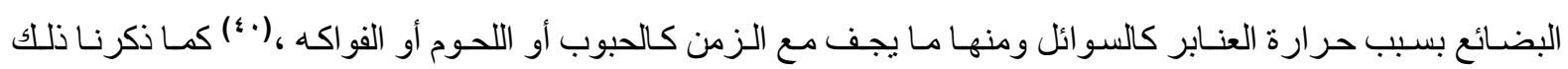
(\$1) سابقان

والجدير بالأشارة في هذا الصدد أنه قد يحصل تداخل و التباس بين البضـاعة التي تكون خطرة والبضـاعة التي

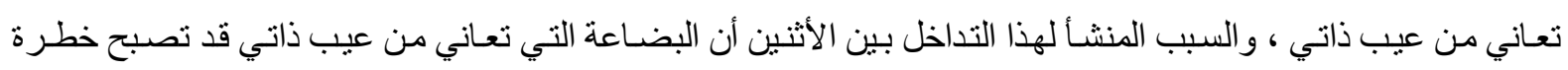

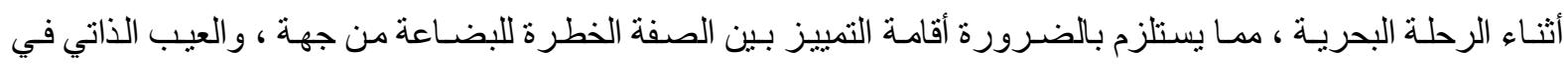

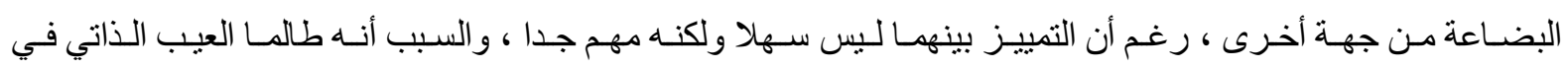

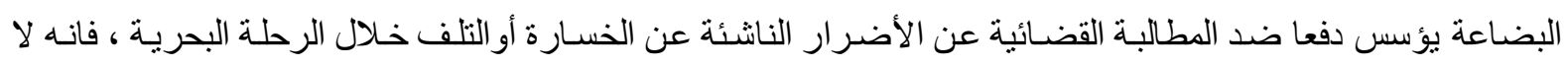

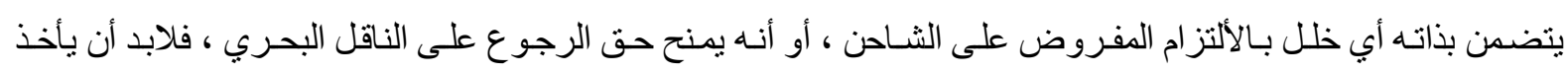

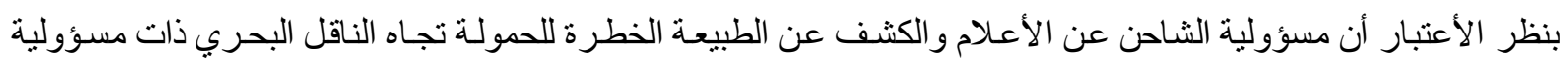

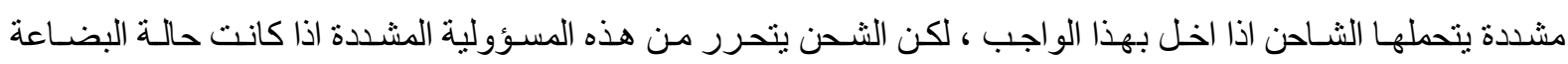
و الصفة الخطرة الني يتحملها واضحة بجلاء وظاهرة العيان للناقل البحري ، فـان الشـاحن سيكون بمنأى من المسؤولية أذا

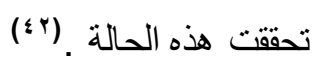

وان اعفاء الناقل بسبب العيب الذاتي يرجع في تقدير فريق من الفقهاء الى الحساق العيب الذاتي بخطأ الشـاحن

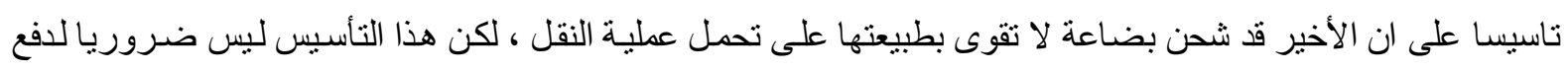

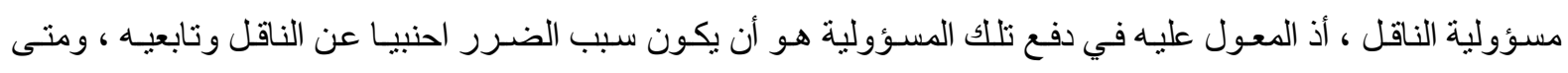

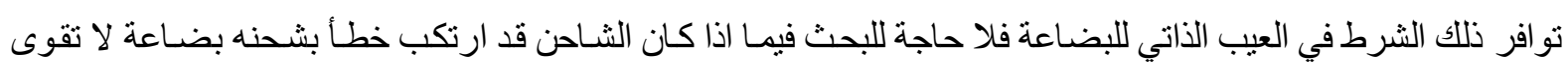

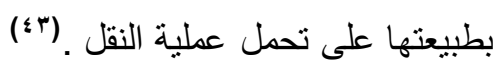

الخاتية

اولا: النتائج

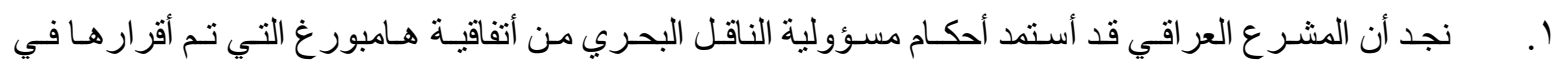

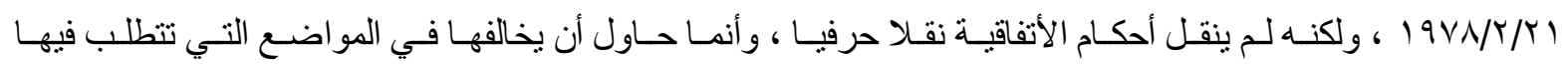

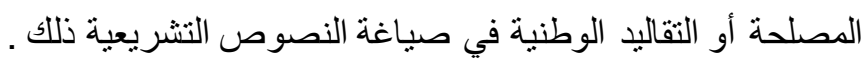




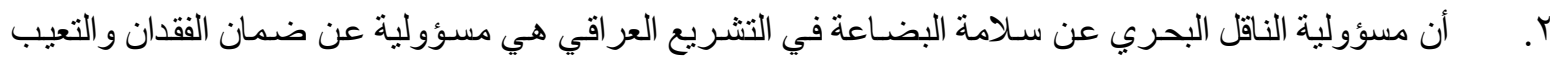

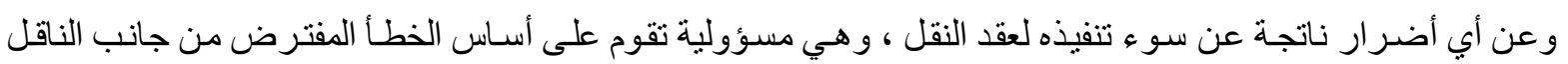
وتابعيه .

r. أن مسؤولية الناقل البحري عن سلامة البضـاعة هي مسؤولية عقديـة يلتزم فيها بتحقيق غايـة وليس بذل عنايـة

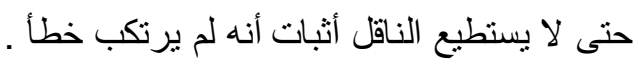
؛. أن مسؤولية الناقل البحري عن سلامة البضـاعة من التلف أو الهلاك تقع على عاتقه منذ التحميل تحت الروافع وتتنهي بتفريغ البضاعة في ميناء التفريغ .

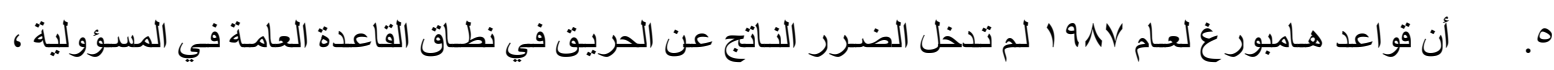

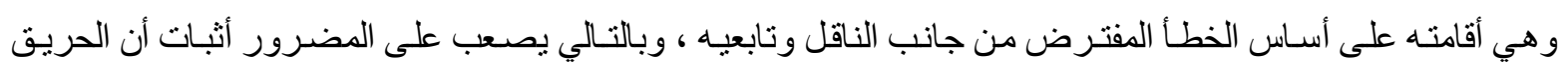

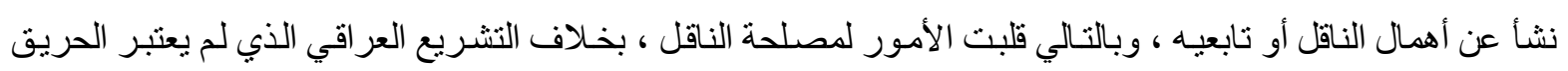

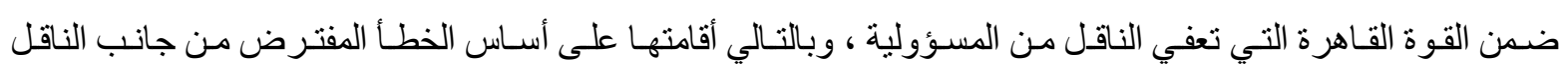
و تابعيه.

آ. أن قواعد روتردام قد جـاءت بقو اعد منوازنـة الى حد بعيد لأسـاس مسؤولية الناقل و الثـاحن راعت فيها قو اعد

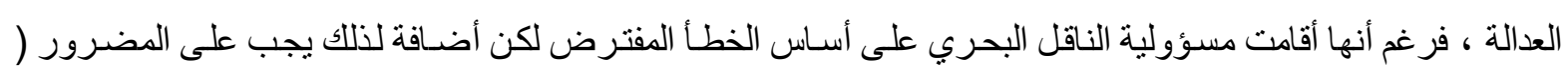
المرسل ) أن يثبت أن تلف البضاعة أو هلاكها قد وقع أثناء مدة التزام الناقل التي حددتها أرادة الطرفين V. في ظل القانون العر اقي يستطيع الثـاحن أن يعفي نفسـه من المسؤولية أو يخفهـا لأن حكم المـادة ( • (/او لا ) لا تخاطب الثاحن وأنما تتعلق بالناقل فقط . ثانيا: التوصيات . ا. . يجب الأسر اع في سن تشريع بحري عر اقي يكون منسجما مع التشريعات البحريـة الحديثة والأتفاقيات الدوليـة البحرية . r. وجوب أنضمام العراق الى الأتفاقيـات الدولية المبرمة في المجـال البحري كأتفاقية روتردام والأقتباس منها في

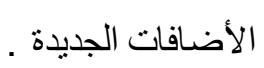

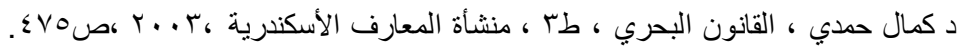

\section{الهوامش}

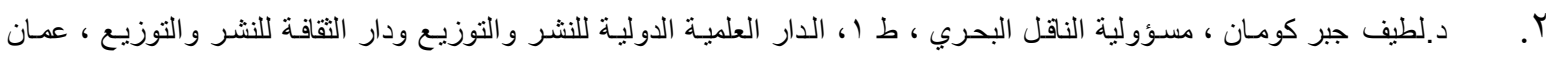

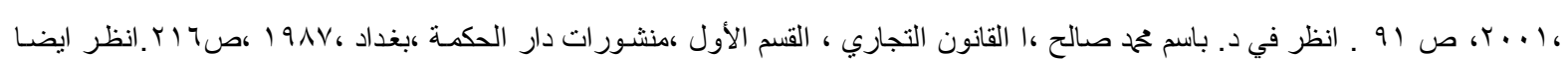

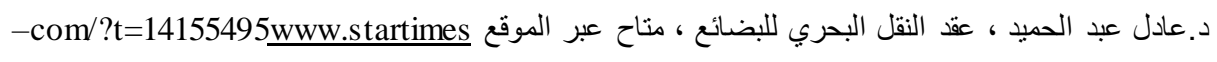
r.

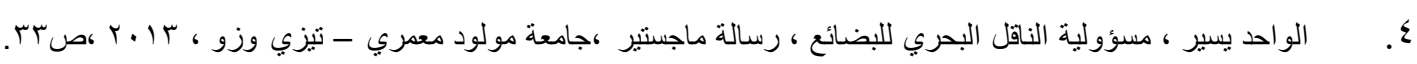

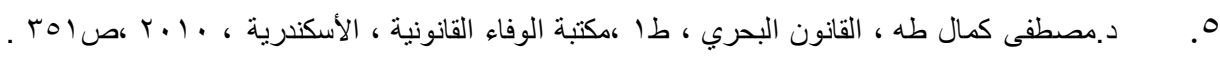

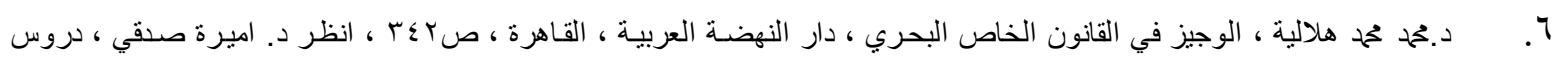

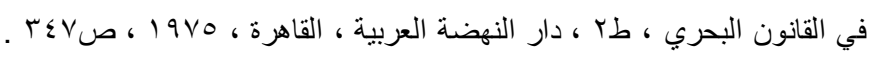




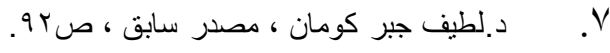

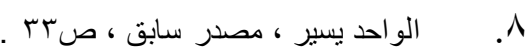

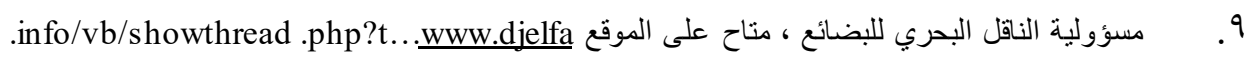

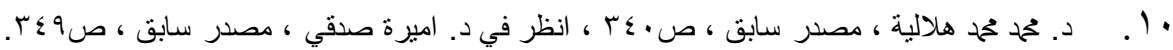

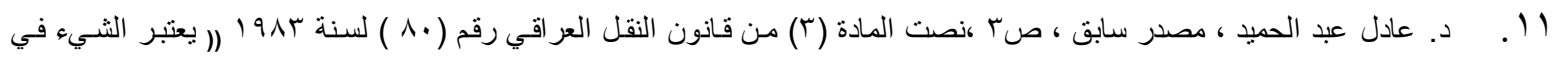
حكم الهالك اذا لم يقم الناقل بتسليمه الى المرسل اليه أو اخطاره بالحضور لتسلمه خلال خمسة واربعون يوما من انقضاء موعد التسليم )) . r ا . . الناقل العام هو الناقل الذي يتعهد لقاء مقابل بتلبية جميع طلبات النقل دون تمييز بينها ، أمـا الناقل الخاص فهو من ينولى النقل بناءا

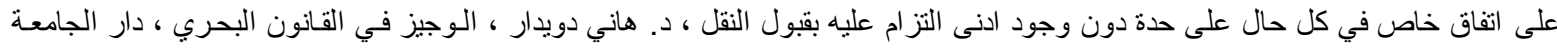

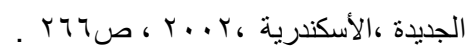

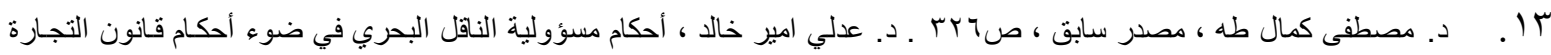

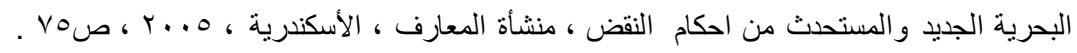

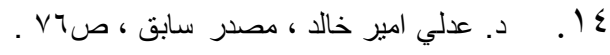

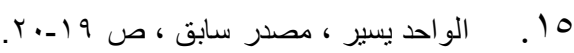

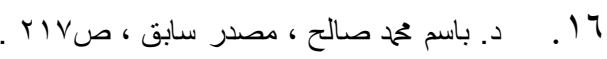

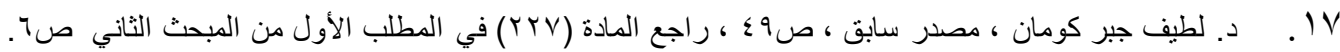

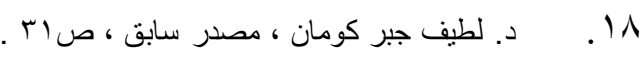

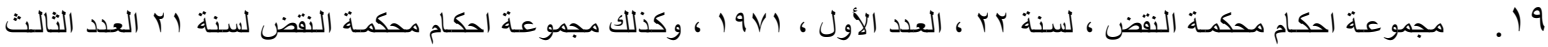

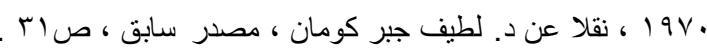

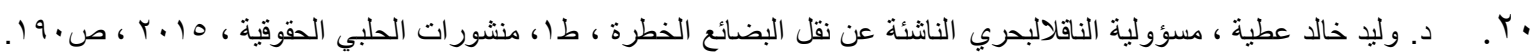

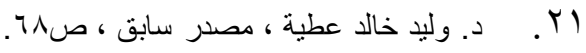

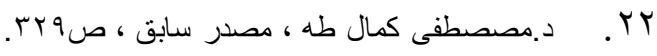

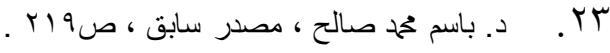

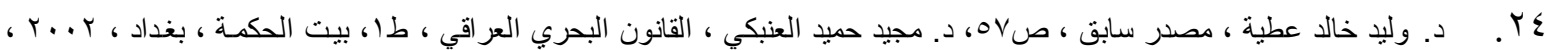

$$
\begin{aligned}
& \text { ص.11. n n }
\end{aligned}
$$

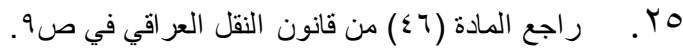

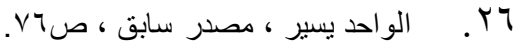

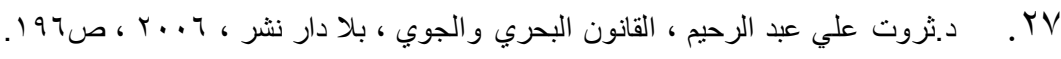

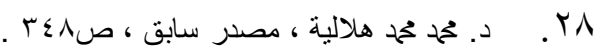

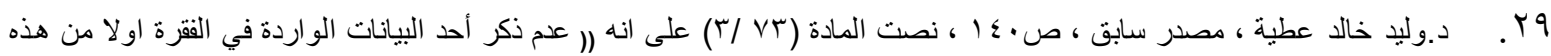

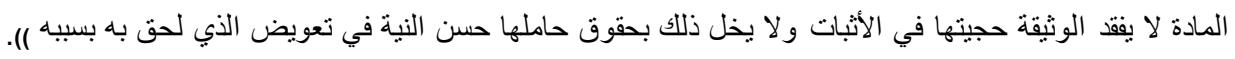

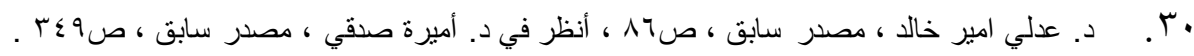

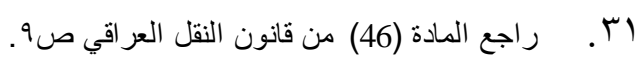

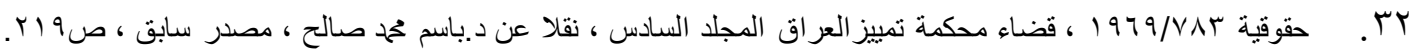

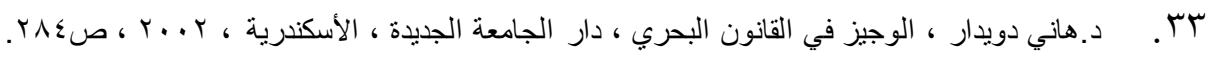

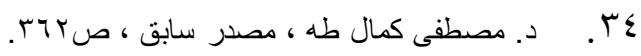

هب . فهر عبد العظيم صالح ، مسؤولية الناقل البحري عن سـلامة البضـائع بين أحكام أتفاقية هـامبورغ و القانون المصري ، بحث منشـور http:www.eastlaws.com. على الموقع 


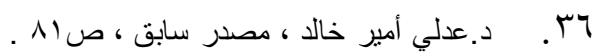

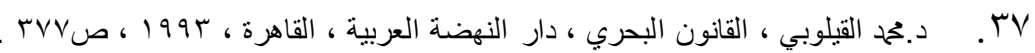

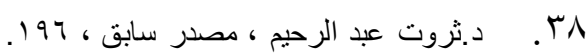

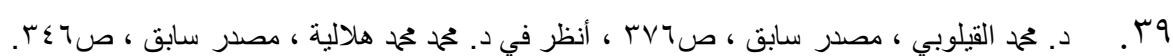

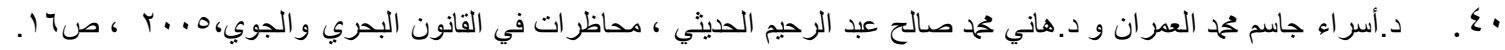

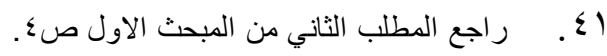

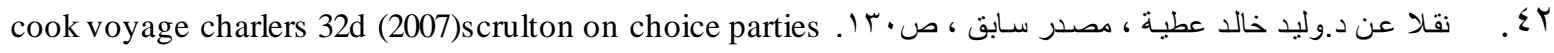

and biiis of lading $\quad$ zoed $\quad$.plg2.

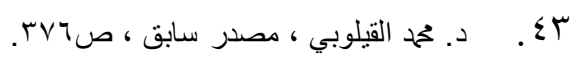

glat|

اولا:الكتب

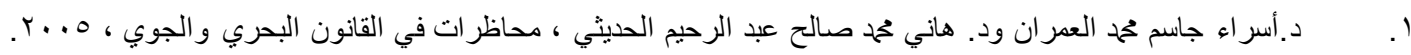

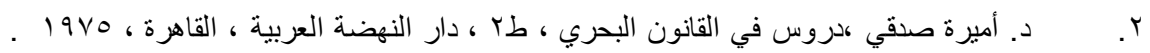

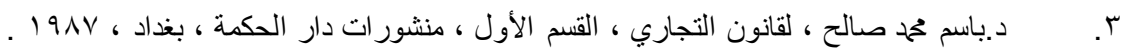

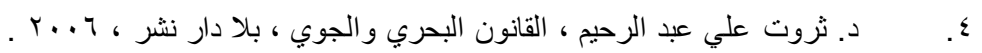

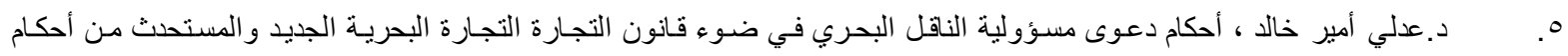

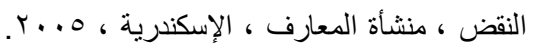

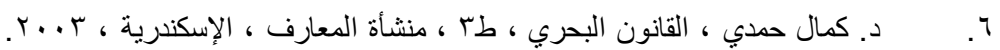

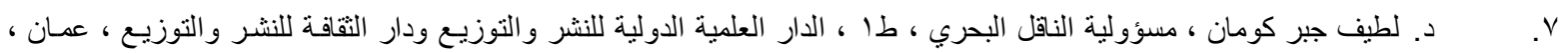

. r. I

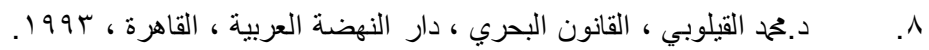

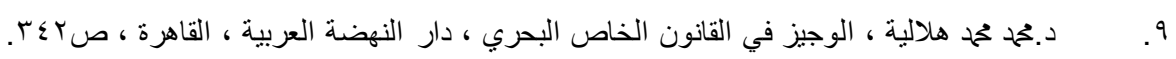

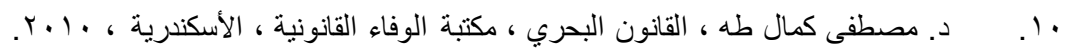

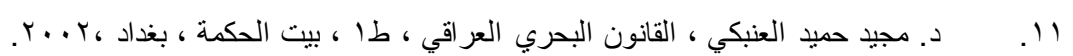

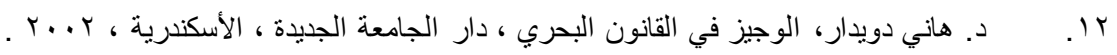

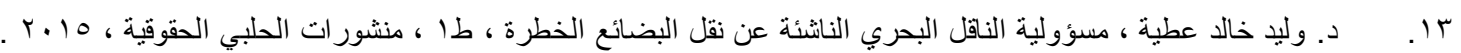

ثانيا: الرسائل.

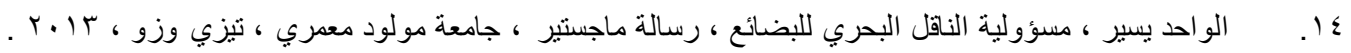

ثالثا : الانترنت .

10. د. عادل عبد الرحيم ، عقد النقل البحري للبضائع ،منشور على الموقع

$. c o m / ? t=14155495$ www.startimes

7 ا. . فهر عبد العظيم صالح ، مسؤولية الناقل البحري عن سـلامة البضـائع بين أحكام أثفاقية هـامبورغ و القانون المصري ، منشور على

الموقع

http//www.eastlaws.com.

IV

.info/vb/showthread .php?t...www.djelfa 